\title{
OSMANLI DEVLETI'NIN İNKIRAZI KARŞISINDA MEKKE ULEMASI: SULTAN II. ABDÜLHAMIID'E GELEN VARAKA ÖRNEĞİ (16 EYLÜL 1879)
}

\begin{abstract}
Hidayet Kara*
$\ddot{\mathbf{O} z}$

Osmanlı Devleti'nin gerilemesi konusu tartışmalı bir mevzudur. Ancak kabul edilmesi gereken şey Osmanlıların, özellikle sanayi devrimi sonrasında Avrupa karşısındaki üstünlüğünü yitirmiş olduğudur. Osmanlı Devleti'nin II. Viyana kuşatmasından sonra hasımları karşısında üst üste yenilgiler alması ve bu yenilgilerin bir sonucu olarak büyük toprak parçalarını kaybetmesi devletin eski ihtişamını yitirdiğinin ilk büyük işaretidir. Osmanlı Devlet adamları kötü gidişat karşısında çareler aramıştır. Devletin kurtuluşunu daima kanun-1 kadime dönmede gören ilk fikirler, 1slahat raporlarına da yansımıştır. Ancak 19. yüzyıla gelindiğinde dünyanın değiştiğini ve kanun-1 kadime dönmenin artık çare olmayacağını gören Osmanlı Devlet adamları ve aydınlar devletin kurtuluşu için çeşitli görüşler serdetmeye başlamışlardır. Bu süreç içerisinde Osmanlı uleması da devletin kötü gidişatının sebepleriyle ilgili ve bu kötü gidişatın durdurulması için fikirler ileri sürmüşlerdir. Ulemanın bir kısmı devletin inkırazının sebebini dini yozlaşmaya bağlamıştır. Devletin kötü durumdan kurtarılmasının yegâne yolunun ise dinin yeniden ihya edilmesinde görmüşlerdir. $\mathrm{Bu}$ amaçla görüşlerini çeşitli yollarla dile getiren ulema kesimi, Sultan II. Abdülhamid'e gönderilen mektup örneğinde olduğu gibi düşüncelerini saraya da iletmişlerdir. Makalede öncelikle gerileme ve terakkiye dair İstanbul'daki ulema ve aydınların görüşlerine yer verilecek daha sonra da Mekke ulemasının Osmanlı Devleti'nin gerilemesine bakışı irdelenecektir.
\end{abstract}

Anahtar Kelimeler: Ulema, Mekke, Osmanlı Devleti, Çöküş, Fikir, Aydın

\section{THE DECLINE OF THE OTTOMAN STATE AND ULEMA OF MAKKAH}

\begin{abstract}
The decline of the Ottoman Empire is a controversial issue, yet what must be accepted is that the Ottomans lost their supremacy against Europe, especially after the industrial revolution. That the state was defeated by its enemies over and over again and hence lost large parts of the land after the second Siege of Vienna was the first sign of it's losing the previous glory. The Ottoman statesmen sought solutions to end the bad progress. The first ideas that saw the revival of the state in the return to the old laws can be observed in the reform reports. However, in the 19th century, Ottoman statesmen and intellectuals began to come up with various views for the revival of the state, seeing that the world had changed and that return to the old laws would no longer be a solution. In this process, the Ottoman ulema group also put forward various ideas for the purpose of
\end{abstract}

Makale Gönderim Tarihi: 04.01.2019, Kabul Tarihi: 03.04.2019

Doi: 10.26791/sarkiat.508413

* Dr. Öğr. Ü., Muş Alparslan Üniversitesi, Fen Edebiyat Fakültesi, h.kara36@hotmail.com

ORCID ID: orcid.org/0000-0001-9642-7890 
stopping the bad situation of the state. Part of the ulema attributed the collapse to the religious degeneration. Thus, the only way to save the state from the worst situation was seen in the restoration of religion. For this purpose, the ulema section which expressed its views in various ways conveyed their thoughts to the sultans too as in in the case of letter sent to Abdulhamid II. In this article, firstly, the views of the ulema and intellectuals in Istanbul will be discussed and then the view of the Ulema of Makkah towards the decline of the Ottoman Empire will be examined. The evaluation of the subject will be given in the conclusion.

Keywords: Ulema, Makkah, Decline, Thought, İntellectual

\section{GíRiş}

Osmanlı Devleti'nin Batı karşısında eski ihtişamını yitirmesiyle başlayan ve büyük toprak kayıplarına sebep olan süreç, ilk başta tamamen içsel zorlamalarla ve yine içe dönük olarak bir takım ıslahat teşebbüslerinin ortaya çıkmasına sebep oldu. Ancak özellikle Lale Devri olarak anılan dönemde Batı ile ilişkilerin gelişmeye başlaması ve Avrupa'da çeşitli başkentlere elçilerin gönderilmesi 1slahatların renginin değişmesine zemin hazırladı. Batı ile başlayan bu yeni ilişki biçimi her ne kadar Osmanlı modernleşmesinde derin izler bırakmasa da yeni bir dönemin ilk işaretleri olması bakımından önemli bir zaman dilimiydi. Bu dönüşüm ağır aksak ve kesintilerle devam etse de süreklilik arz etti. Sultan III. Selim dönemine kadar yapılmaya çalışılan 1slahatlar İslâm kültürü çerçevesini aşmayan ve bu kültür dairesinde olan yeniliklerdi. Ancak özellikle Sultan II. Mahmud döneminde Yeniçeri Ocağının lağvedilmesiyle başlayan yeni modernleşme hareketleri, Batılı yaşam tarzının taşıyıcısı olduğundan yeni tartışmaları da beraberinde getirdi.

Tanzimat Ferman'ının ilanına müteakip, Avrupa'da bilim, teknoloji, siyasi düşünce, hukuk, eğitim, maişet, zihniyet ve moda gibi alanlarda meydana gelen gelişmeler Osmanlı Devlet yöneticilerinin yanı sıra, aydın ve ulema kesimini de derinden etkilemeye başladı. Osmanlı devlet adamları bu süreç içerisinde Batı'dan birçok alanda kanunlar iktibas ederek hem kurumsal anlamda hem de toplumsal anlamda büyük bir dönüşüme sebep oluyorlardı. ${ }^{1} \mathrm{Bu}$ dönemde hukuksal alanda yapılan veya yapılmak istenen yenilikler, Osmanlı toplumunu derinden etkiledi. Cevdet Paşa Tezakir'de bu dönemde hukuk alanında yapılan iktibasların doğru olmadığını, çünkü bir milletin kanunlarını başka bir medeniyeti esas alarak değiştirmenin, o milleti imha anlamı taşıdığını ifade ediyordu. ${ }^{2}$ Esasında çoğu Osmanlı devlet adamı ve aydını için maddi anlamda Batılılaşmak devletin kurtuluşu adına şarttı. ${ }^{3}$ Ancak devletin hangi yolla kalkınacağına ve Batı'dan ne suretle yararlanılacağına dair tartışmalar sürüp gidiyordu. $\mathrm{Bu}$ durum da tıpkı birincisinde olduğu gibi şüphesiz toplumun dönüşümünde önemli bir rol oynuyordu. Temelde dağılmakta olan devleti kurtarmayı amaç edinen girişim ve düşünceler, Osmanlı aydınları arasında fikir ayrılıklarının doğmasına da zemin hazırladı. Osmanlı devlet adamlarının/aydınlarının amaçları aynı olmakla birlikte,

\footnotetext{
${ }^{1}$ Cartrer V. Findley, Osmanlı Imparatorluğu'nda Bürokratik Reform Babıâli, 1789-1922, trc. Ercan Ertürk, (İstanbul: Tarih Vakfı Yurt Yayınları, 2014), 181.

${ }^{2}$ Ahmet Cevdet Paşa, Tezakir, haz. Cavid Baysun, (Ankara: Türk Tarih Kurumu Yayınları, 1953), 1: 63. Osman Öztürk "Osmanlılarda Tanzimat Sonrası Yapılan Hukukî Çalışmalar ve Mecelle-î Ahkâm-1 Adliye", Osmanlı, (Ankara: Yeni Türkiye Yayınları 1999), 6: 504.

3 Tarık Zafer Tunaya, Türkiye'nin Siyasî Hayatında Batılılaşma Hareketleri, (İstanbul: İstanbul Bilgi Üniversitesi Yayınları, 2010), 31-33. Bkz. Niyazi Berkes, Türkiye’de Çağdaşlaşma, haz. Ahmet Kuyaş, (İstanbul: Yap1 Kredi Yayınlar1), 2002, 381-386.
} 
devletin inkırazının sebeplerini ortaya koyma ve buna çare arama konusunda farklı fikirleri vardı. Avrupa'daki gelişmelerin sadece teknik yönüyle alınması gerektiğini savunanlar olduğu gibi, Batı'nın gülüyle dikeniyle bir bütün olarak taklit edilmesi gerektiğini ifade edenler vardı. ${ }^{4}$ Ulemadan ve üçüncü olarak sayabileceğimiz bir grup ise Osmanlı Devleti'nin mevcut durumunun sebebini tamamen dinin ifsat olmasina, Müslümanların dinlerini anlamamasına ve yaşamamasına bağlıyordu. Ulema bu konuda tek renk olmasa da genel eğilim bu yöndeydi. Osmanlı aydınlarının/ulemasının veya devlet adamlarının modernleşme konusundaki tavrı ne olursa olsun, sonuç olarak İslâm kültürü ile Batı değerleri arasında bir tercihi gerektiriyordu. Orhan Okay'ın ifadesiyle bu süreç “....iki değerler sisteminin karşılaştırılması ve sonucunda tercih ve kabullerde bulunulmast..." ile ilgili bir süreçti. ${ }^{5}$

"Hâkim medeniyet" karşısında Müslüman ulema ve münevverlerin tartışmaları sadece Batı'dan neyin iktibas edileceğiyle sınırlı kalmadı. Batı'dan alınan her bir yenilik, aynı zamanda yeni bir tartışmanın da kapısını araladı. Modernleşmeye dair tartışmalarda ulema ve aydınları meşgul eden önemli konulardan birisi "İslâm Mâni-i Terakki midir?" sorusuydu. Bu tartışma XVIII. ve bilhassa XIX. yüzyıl Avrupa'sında, İslâm dininin terakkiye izin vermediği ve Müslümanlar dinlerini terk etmedikçe terakki edemeyeceklerine yönelik Renan'ın meşhur İslâm ve Bilim nutkundan sonra yoğunluk kazanmıştı. ${ }^{6}$

Tartışmanın bütün boyutlarıyla ortaya çıkarılması, ulemanın devletin parçalanışı karşısındaki tavrının tespiti ve çözüm arayışlarındaki fonksiyonunun ortaya koyulması bu makalenin sınırlarını aşmakla birlikte, özel bir örneklem olarak Arap ulemasından saltanatının ilk yıllarında Sultan II. Abdülhamid'e gelen ve Osmanlı Devleti'nin çöküşünün sebeplerini irdeleyen mektup/belge merkeze alınarak bir tahlilde bulunulmaya çalışılacaktır. Her ne kadar bazı yönleriyle konu eksik kalacaksa da makale önemli bazı soruları gündeme taşıyacağı ve daha kapsamlı bir çalışmanın temeli ve başlangıcı olacağı düşünülmektedir.

\section{Osmanlı Aydınlarının Dini Müdafaası: “İslâm Terakkiye Mâni Değildir”}

XIX. yüzyıl Osmanlı Devleti için çözülmenin arttı̆̆ı, bu çözülmenin devlet adamlarını ve aydınları parçalanmayı durdurmak ve elde kalan toprakları muhafaza etmek için büyük arayışlara ittiği bir dönemdi. Pek tabbii olarak, devleti kurtarma çabaları çeşitli fikir akımlarının doğmasına da zemin hazırladı. Osmanlıcılık, İslâmcılık, Türkçülük ve Batıcılık olarak tesmiye edilen fikirlerin takipçileri, keskin çizgilerle birbirinden ayrılan

\footnotetext{
${ }^{4}$ Osmanlı aydınları arasında Batılılaşmanın ne yolla olacağına dair tartışmalar uzun süre devam eden bir olgu olsa da İlber Ortaylı'nın ifadesiyle 19. Yüzyılda İstanbul ve büyük liman şehirlerinde yeni bir hayat başlamıştı. Geniş bilgi için bkz. İlber Ortaylı, "Tanzimat Adamı ve Tanzimat Toplumu”, Tanzimat, Değişim Sürecinde Osmanlı Imparatorluğu, haz. Halil İnalcık-Mehmet Seyidanlıŏlu, (Ankara: Phoenix Yayınları, 2006), 301-334. Bahattin Çatma, "Abdullah Cevdet'e İctihadî Bir Bakış: Vefatının Ardından Hakkında Yazılanlar Üzerinden Bir Portre Denemesi”, Geçmişten Günümüze Malatya Uluslararası Sempozyumu Kent, Kültür ve Kimlik, (Malatya: 14-16 Nisan 2016), 1103-1104.

${ }^{5}$ Orhan Okay, Batılılaşma Devri Türk Edebiyatı, (İstanbul: Dergâh Yayınları, 2016), 12.

${ }^{6}$ Geniş bilgi için bkz. Dücane Cündioğlu, "Ernest Renan ve "Reddiyeler" Bağlamında İslâm-Bilim Tartışmalarına Bibliyografik Bir Katkı”, Divan, 1/2, (İstanbul: 1996), 4. On dokuzuncu ve yirminci yüzyıl şarkiyatçıları esasında sadece İslâm coğrafyasıyla ilgili değil bütün bir doğu ile ilgili menfi düşüncelere sahipti. Edward Sait'in değişiyle doğu hakkında olumlu fikirlere sahip olmayan batılı bu sosyal bilimciler "Doğuyu Doğululaştırmak" için yoğun çaba sarf ediyordu. Örneğin Karl Marx İngilizler doğuyu mahvederken bile sosyal bir patlamaya hizmet ettiklerini açıklamaya çalışıyordu. Edward Said, Oryantalizm, trc. Nezih Uzel, (İstanbul İrfan Yayınları, 1998), 2016. Ayrıca Renan için bkz. Aynı eser, 188-216.
} 
gruplar olmasa da devletin kurtuluşu için özünde farklı düşüncelere sahipti. Devletin nasıl terakki edeceği ve "medeniyetin yolunu" takip etme hususunda keskin fikir ayrılıklarına sahip olan Osmanlı aydınları/ulema, inkırazın durdurulması için değişimin şart olduğu noktasında hemfikirdi. ${ }^{7}$

Her ne kadar birçok yazılı metinde aydınların belli bir kalıba sokulmayacağı belirtilip, çoğu zaman bir aydının hem Batıcı hem Türkçü veya hem Türkçü hem İslâmcı olabileceği ifade edilse de devletin kurtuluşunun İslâm kültürü dairesinde mi olacağ1 yoksa Batı medeniyeti dairesine mi girileceği hususunda aydınlar arasında fikir çatışmaları vardı. Çünkü bahsi geçen konu açısından bakıldığında kimi Osmanlı aydınları ve uleması devletin kurtuluşunu İslâmî esasların yeniden ihya edilmesinde görüyorken, kimi Osmanlı aydın çevreleri ise -İçtihat Gazetesi çevresi gibi- bütün yönleriyle Batı medeniyetinin taklit edilmesi gerektiği düşüncesini taşıyordu. ${ }^{8}$ Çünkü onlara göre Batı öğretendi. Açıkçası bu durum, Osmanlı aydınları arasında medeniyet tercihi açısından düşünsel bir kırılmanın olduğunu gösteriyordu.

Modernleşme ve dinin modernleşme karşısındaki durumu, Tanzimat dönemi öncesinde de tartışılan bir konuydu. Bundan olsa gerek, Osmanlı sultanları yaptıkları hemen her 1slahatı bir şekilde din ile temellendirmeye çalışmışlardı. Sultan III. Selim'in, yeni orduyu kurarken dinî referans olarak alması ${ }^{9}$ veya Sultan II. Mahmud'un yaptı̆̆ 1 1slahatların ulema ve halk arasında bir tepkiyle karşılanmaması için dönemin Şeyh'ülislâmı Abdülvehhâb Efendi'ye, sultana itaatin farz olduğu yönünde bir risale yazdırması bahsedilen durumun en önemli örnekleri arasındadır. ${ }^{10}$ Tanzimat döneminde girişilen 1slahat faaliyetleri, din ile Batılılaşma çabaları arasındaki zıtlıkları veya en azından Batı'yı taklit meselesindeki problemli tarafları daha görünür kıldı. Kuşkusuz bu durum yeni tartışmalarında kapısını araladı. Tanzimat dönemiyle birlikte başlayan sürecin ilk devresi mebde-i saadet nin başlangıcı yani "saadet dönemi” olarak görüldü. Ancak Âlî ve Fuat Paşalar ile başlayan ikinci dönem, Namık Kemal tarafından İslâm'a ve halka yabancılaşmanın başlangıcı olarak tarif edildi. Namık Kemal'in bu düşüncesi esasında Genç Osmanlıların genel kabulü gibiydi. Onlar Tanzimat döneminde başlayan Batılı yaşam tarzını taklit etmeyi ahlaki bir problem olarak gördüler. Gencer' in aktardığına göre Ziya Paşa, devlet adamları ve bakanlar arasında başlayan alafrangalık âdetinin topluma sirayet ederek millî ahlakı yozlaştıracağından şikâyet etmişti. ${ }^{11}$ Yine Namık Kemal söz konusu Avrupa'yı işe yarar yönlerini değil de "dans, tiyatro, balo, eşini kıskanmama "vs. gibi kültürel unsular üzerinden takip etmenin devlete bir fayda sağlamayacağını belirtiyordu. $\mathrm{O}$, bu tür bir modernleşmeye taraftar olmadığını "bin kere istemeyiz" diyerek ifade etmişti. ${ }^{12}$ Ali Suavi'de bu konuda Namık Kemal ve Ziya

\footnotetext{
${ }^{77}$ Kemal H. Karpat, İslâm’ın Siyasallaşması, (İstanbul: İstanbul Bilgi Üniversitesi Yayınları, 2010), 189. Esasında "Terakkî fikriyatçılığ Condorcet ve Kant'ta kemalini bulduktan sonra..." düşüncesi ne olursa olsun neredeyse hiçbir aydının itiraz etmediği veya edemediği bir kavramdı. Mustafa Şekip Tunç, Terakki Fikri, haz. Osman Bahadır, (İstanbul: Anahtar Yayınları, 2005), 148.

${ }^{8}$ Hidayet Kara, "İkdamcı Cevdet'in İsviçre Notları Işığında Osmanlı Aydınının Batı Algısı", History Studies, 10/ 7, (Ekim 2018): 167.

${ }^{9}$ Ziya Paşa, Tercî-i Bend, Terkibi-i Bend, nşr Hüseyin Yorulmaz, (İstanbul: Çıdam Yayınları, 1992), 119122.

${ }^{10}$ Esra Yakut, Şeyhülislamlık Yenileşme Döneminde Devlet ve Din, (İstanbul: Kitap Yayınevi, 2014), 50.

${ }^{11}$ Bedri Gencer, İslâm'da Modernleşme 1839-1939, (Ankara: Doğu Batı Yayınları, 2012), 500.

12 Nurullah Çetin, "Ziya Paşa”, Tanzimat Edebiyatı, haz. İsmail Parlatır, (Ankara: Akçağ Yayınları), 2006, 181. Ziya Paşa, dinin terakkiye mâni olmadı̆̆ı bildirmekle birlikte İslâm dünyasıyla Batıyı karşılaştırmış ve Batının gelişmişliğine karşı İslâm dünyasının virane halde olduğunu ifade etmiştir. "Diyar-ı Küfrü gezdim beldeler kâşâneler gördüm/Dolaştım mülk-i İslâm-ı bütün virâneler gördüm/ Buldum ben dahi Dârrüşşifayı Bâb-ı Âli'del Felâtun beğenmez anda çok divaneler gördüm." İnci
} 
Paşa ile aynı fikirdeydi. ${ }^{13}$ Bahsi geçen düşünürler İslâm dinin Batılıların ortaya attığı gibi terakkiye mâni olmadığı konusunda hemfikirdi. Ziya Paşa İslâm'ın mâni-i terakki olduğuna yönelik ithamlarda bulunanlara karşı şu beyitleri yazmıştı:

"İsnâd-ı taassub olunur merd-i gayûra

Dinsizlere tevcih-i reviyyet yeni çıktı

İslâm imiş devlete pâ-bed-i terâkkî

Evvel yoğidi işbu rivâyet yeni çıktı

Milliyeti nisyan ederek her işimizde

Efkâr-ı Frenge tebaiyyet yeni çıktı

Eyvah bu bâzîçede bizler yine yandık

Zîrâ ki Ziyan ortada bilmem ne kazandık,"14

Namık Kemal de dinin mâni-i terakkî olduğunu söyleyenlere tepki göstererek, eğer İslâm devletin ilerlemesinin önünde bir engel ise Avrupa kültürünün temeli olan Endülüs'ün Müslümanlar tarafindan nasıl olurda kurulabildiğini haklı olarak soruyordu. Ona göre de terakkiye mâni olan din değildi. Aksine kurtuluşunun yegâne yolu dindi. ${ }^{15}$ Kemal, İslâm'ın ve Osmanlı milliyetçiliğini tek çıkar yol olarak görmekle birlikte, Batı medeniyetinde ki gelişmeleri de göz ardı etmemişti. ${ }^{16} \mathrm{Bu}$ tasavvur Tanzimat dönemi ulema ve aydınları arasında yaygın olduğu gibi gerek Sultan II. Abdülhamid ve gerekse II. Meşrutiyet dönemi ulema ve İslâmcı aydınları arasında da yaygındı. Dinin ihya edilmesini savunan Osmanlı aydınları/uleması, devletin gerilemesinin sebeplerine dair fikirlerini beyan ederken sık sık dikkat çektikleri husus Müslümanların dinlerini yaşamadıkları ve İslâm dinini yeterince tanımadıkları hususuydu. Osmanlı aydınlarının, siyasal gerileyişiyle, dinî yozlaşmayı paralel olarak ele alması esasında indirgemeci bir yaklaşım biçimiydi. Çünkü bu düşünce devletin içinde bulunduğu durumu açıklamak için yetersizdi. ${ }^{17}$

Enginün, Yeni Türk Edebiyatı Tanzimat'tan Cumhuriyet'e (1839-1923), (İstanbul: Dergâh Yayınları, 2010), 475. Taklit meselesiyle ilgili bakınız, Hasan Hikmet, "Taklid Seyyiesi”, Sebilürreşad, 21, 212213.

${ }^{13}$ Gencer, Íslâm'da Modernleşme, 500

14 Ali İhsan Kolcu, Tanzimat Edebiyatı I, (Erzurum: Salkım Söğüt Yayınevi, 2008), 129. Ziya Paşa gazete yazılarıyla da mevcut durumu eleştiriyordu. "Avrupa'yı taklitle ileri gitmek iddiasında bulunduğumuz halde Avrupa'da görülen kanunlara riâyet, sanâyiin terakkisi, ticaretin genişlemesi ve hukûkun temini gibi terakkinin sebeplerinden hiç birini taklit etmeyip, fakat tiyatro yapmak, baloya gitmek, zevcesini kıskanmamak, tahâretsiz gezmek gibi şeylere yöneldiğimizi, Osmanlılara mahsûs olan mürüvvet, hamiyyet, edeb, âcize merhamet, hukûka riâyet, misâfire hürmet, diyânet, emânet, şecâat gibi güzel şeyler günden güne içimizden çekilip, cehâlet, zillet, denâet, irtikâp, hıyânet gibi zemmedilmesi gereken neşv ü nemâ bulmasını hayretle görüp bizi bildikleri akvâmdan hiç birine benzetmezler. ... Biz ahlâkımızı bu şekilde bozup gidersek ileride başka bir dış tehlikeye hâcet kalmaksızın milletimizin, mumun kendi kendine yanıp tükenişi gibi söneceği hiçbir akl-1 selîm için yanlış bir benzetme değildir." https://vahadergisi.wordpress.com/2007/02/17/batiyi-seven-ziya-pasa-baticilardan-sikayetci/ (Erişim Tarihi: 19.09 .2018$)$

${ }^{15}$ Abdullah Uçman, "Namık Kemal”, Tanzimat Edebiyatı, haz: İsmail Parlatır, (Ankara: Akçă̆ Yayınları, 2006), 231.

16 Bkz. Mithat Aydın, "Namık Kemal'de "Terakki” ve "Maarif” Düşüncesi, Ankara Üniversitesi Dil, Tarih, Coğrafya Fakültesi Dergisi, 53/2, (2013), 452-477.

17 İsmail Kara, Din ile Modernleşme Arasında Çağdaş Türk Düşüncesinin Meseleleri, (İstanbul: Dergâh Yayınlar1, 2014), 87. 
XIX. ve XX. yüzyılların önemli özelliklerin birisi de Kur'an'ın bazı isimler ve çevreler tarafından modern bilim mantığı çerçevesinde ele alınmasıydı. Mevzu bahis isimlere ve çevrelere göre Kur'an bütün teknik ve bilimsel ilerlemeleri içinde barındırıyordu. Dolayısıyla İslâm coğrafyasının büyük çoğunluğunun sömürge ya da yarı sömürge durumuna gelmesinin sebebi din olamazd1. ${ }^{18}$ Osmanlı aydınları modern bilimler karşısında dini müdafaa için böyle bir söylemi tercih ediyorlardı. İsmail Kara bu durumu şöyle ifade etmiştir:

"Dinin yerini alma iddiasında olan insan merkezli ve akılcl-deneyci modern bilimin, İslâm dininin hususen Kuran'ın mucizeliğinin, XIX. Asrın pozitivist mantı̆̆ içinde savunulması için uygun bir araç olduğuna/olabileceğine dair bir kanaat oluş(turul)muş ve "İslâm'ın mâni-i terakkî” olduğu, bilimle, akılla barışık olmadığı yolundaki oryantalistik tezleri çürütmek veya bu ă̆ır yükten nisbî de olsa kurtulmak doğrultusunda çokça çaba sarf edilmiştir. "19

Dinin terakkiye mâni olmadığını esasında terakkinin kaynağı olduğunu söyleyen Osmanlı aydınlarının çoğu, devletin modernleşme çabalarını şartlı olarak destekliyordu. İslâmcı aydınlar diyebileceğimiz bu grup Avrupa'dan teknik ve bilimsel açıdan yararlanılması gerektiğini ifade ediyordu. Onlara göre sakıncalı olan şey teknikle birlikte kültürün taklit edilmeye başlanmasıydı. Modernleşme konusunda ifade edilen noktadan hareket eden aydınların çoğu dinin yanlış yorumlandığını ifade ederek, bu konuda maziye yönelik büyük eleştireler yöneltiyordu. Örneğin merhum Akif Safahat'ta "Durmayalım" isimli şiirinde şunları dile getiriyordu.

İşte âtidir o ser-menzil denen ârâmgâh;

Kârbân akvâm; çöl mâzî; atâlet sedd-i râh.

Durma mâzî bir mugaylanzâr-ı dehşetnâkdir;

Git ki, âti korkusuzdur hem de kudsî haktir! ${ }^{20}$

Mehmet Akif (Ersoy) İstiklal Marşı'nda her ne kadar medeniyeti (Batı medeniyeti) tek dişi kalmış canavar olarak betimlese de teknik ve bilimsel ilerlemelerin Avrupa'dan iktibas edilmesine karşı değildi. Memleketin kötü durumunun, Müslümanların kendi yüzünden olduğunu ifade eden Akif: "Bu kanll felaketler yok mu, işte, işte onlar bizim kendi yüzümüzden evet, hiç kimsenin değil..." diyordu. ${ }^{21}$ Terakki adlı şiirinde de Bir milletin başka yerlerde çareler arayarak değil, ancak kendi içinde problemlerine çözümler üreterek yükseleceğini belirtiyordu. ${ }^{22} \mathrm{Bu}$ noktada Akif, terakkinin Müslümanların dinlerini doğru bir şekilde anlayıp, ondan uygun bir şekilde yararlanmalarıyla mümkün olacağı inancındaydı. ${ }^{23}$ Daha öncede belirtildiği üzere ulema bu konuda hemfikirdi. Ancak dinle ilgili yapılacak reformlar konusunda ulemanın bir uzlaşı içinde olduğunu söylemek mümkün değildir. 1909'da Mustafa Sabri ile Manastırlı İsmail Hakkı arasında basın üzerinden cereyan eden münakaşa irdelendiğinde, ulema arasında reformlara ciddi çekinceler koyan bir kesim olduğu

\footnotetext{
${ }^{18}$ Kara, Din ile Modernleşme Arasında, 87.

${ }^{19}$ Kara, Din ile Modernleşme Arasinda, 89.

${ }^{20}$ Mehmet Akif Ersoy, "Süleymaniye Kürsüsünden", Safahat, haz. M. Ertuğrul Düzdağ, (İstanbul: İz Yayıncilık, 1991), 22.

${ }^{21}$ Eşref Edip, Mehmet Akif, haz. Fahrettin Gün, (İstanbul: Beyan Yayınları, 2011), 84.

${ }^{22}$ Bkz. Mehmet Akif Ersoy, "Süleymaniye Kürsüsünden”, 176.

${ }^{23} \mathrm{Bkz}$. http://mehmetakifarastirmalari.com/2016/02/28/suleymaniye-kursusunde/ (erişim tarihi29. 04. 01. 2019). Cündioğlu, "Ernest Renan ve "Reddiyeler", 8.
} 
anlaşılır. Buna karşı reformların gerekliliğini savunan başka bir kesimin de var olduğu net bir şekilde görülür. ${ }^{24}$ Keza II. Meşrutiyet döneminde Mecelle'nin tadiliyle ilgili çıkan tartışmalarda da ulemanın keskin bir şekilde ikiye ayrıldığı görülmektedir. ${ }^{25}$ Ulema şerh koyduğu konular olsa da devletin bekası için reformları ve Batı'dan bu anlamda yararlanmayı uygun buluyordu. ${ }^{26}$ Ahmet Hamdi Akseki, İslâm dininin bütün dinlerden, ideoloji ve düşüncelerden daha çok ilerlemeyi teşvik ettiğini belirtiyordu. Konuyu "iki günü müsavi olan aldanmıştır" hadisini örnek vererek açıklıyordu. Onun düşüncesine göre İslâm dini eğer terakkiye mâni olsaydı, muazzam İslâm medeniyetinin ortaya çıkması, yüz yıllarca ilerleme yolunda öncülük etmesi mümkün olamayacaktı. ${ }^{27}$ Ulemaya göre İslâm toplumunun geçmişteki zafer dolu ve şerefli durumu ile şimdiki yenilmişlik psikolojisi ve içine düşmüş olduğu zillet arasında büyük bir tezat vardır. ${ }^{28}$ $\mathrm{Bu}$ durumun müsebbibi kuşkusuz öncelikle yine Müslümanların kendisidir. İzmir Mebusu Mehmed Seyyid Bey, bahsi geçen düşüncelere farklı bir boyut katarak ulemanın Batı'yı yeterince tanımadığını, bundan ötürü iyi şeylere dahi kötü dediğini ve caiz olmadığı hükmünü verdiğini belirtir. ${ }^{29}$ Said Halim Paşa da bu konuda Seyyid Bey ile benzer fikirlere sahiptir. ${ }^{30}$ Ayrıca Paşa'ya göre dini gerilemenin sebebi olarak görenler, İslâm'a dair bilgisi olmayanlardır. ${ }^{31}$ Belirtilmesi gereken bir hususta terakkinin ne olduğudur. Elmalı Hamdi "alelıtlak bir terakkî-i beşer" yani genel bir terakki tanımı yapılamaz der. ${ }^{32}$ Ayrıca Elamalı, İslâm dininin terakkiye mâni olmadı̆̆ gibi, ilim ile de muarazayı kabul etmediğini belirtir. ${ }^{33}$ Ahmet Hamdi Akseki de terakkinin tek tanımının olmadığını beyan edenlerdendir. Toplumların, kendi düşüncesine, kültürüne, medeniyetine göre hedeflediği amaca ulaştığında terakki etmiş olacağını ifade eder. ${ }^{34}$

\footnotetext{
${ }^{24}$ Geniş bilgi için bkz. Ahmet Bein, Osmanlı Uleması ve Türkiye Cumhuriyeti, (İstanbul: , Kitap Yayınevi 2013), 56-57.

${ }^{25}$ Bein, Osmanlı Uleması ve Türkiye Cumhuriyeti, 59-61.

${ }^{26}$ Devletin bekası için Batı'nın taklit edilebileceğini belirtenlerden biri de İskilipli Atıf Hocadır. Konuyla ilgili düşünşeleri için bkz. İskilipli Atıf Hoca, "Batıyı Taklit Etmek ve Medeniyet Meseleleri”, Türkiye'de İslâmcılık Düşüncesi, haz. İsmail Kara, (İstanbul: Dergâh, 2011)

27 İslam ulama ve aydınlarını meşgul eden sadece İslam ve terakki meseleleri değil aynı zamanda Batıların İslam'a bakışıydı. Bkz. Ahmet Hamdi Akseki, "İslâm ve Terakkî" Türkiye'de İslâmcılık Düşüncesi-2, (İstanbul: Dergâh, 2011), 877.

28 Babanzade Ahmed Naim'de Müslümanların dinlerini yeterince anlamamış olmalarının bu durumu doğurduğunu belirtir. Enfal (8/60) süresinden örnek veren Babanzade Müslümanların bütün ileri şeylere talip olması gerektiğini ifade eder. Bkz. ${ }^{28}$ Babanzade Ahmed Naim, "İslâmiyet'in Esasları Mâzî ve Hali", Sebilürreşad, 12/284, 373. Babanzade Ahmed Naim, “İslam'ın Dünü ve Bugünü” Türkiye'de İslâmcılık Düşüncesi-1, haz. İsmail Kara, (İstanbul: Dergâh, 2011), 344. Benzer düşünceler İzmir Mebusu Mehmed Seyyid Bey tarafından da dile getirilir. Bkz. Seyyid Bey, "İçtihat ve Taklit", Türkiye'de Íslâmcılık Düşüncesi-1, haz. İsmail Kara, (İstanbul: Dergâh, 2011), 267-27.

${ }^{29}$ Seyyid Bey, "İçtihat ve Taklit", 267-27.

30 Said Halim Paşa, "İslâm Aleminin Gerilik Sebepleri Üzerine Deneme", Buhranlarımız, haz. Selçuk Demirbağ, (Tercüman 1001 Temel Eser), 174-175.

Said Halim Paşa, "İslâm Âleminin Gerileme Sebepleri Üzerine Bir Deneme”, Türkiye'de İslâmcılık Düşüncesi-1, haz. İsmail Kara, (İstanbul: Dergâh, 2011), 213-214.

${ }^{31}$ Said Halim Paşa, Buhranlarımız, 177-178. Said Halim Paşa'nın konuyla ilgili düşünceleri için bkz. Said Halim Paşa, Bütün Eserleri, haz. N. Ahmet Özalp, (İstanbul: Büyüyen Ay Yayınları, 2015), Said Halim Paşa, "Meşrutiyet", Buhranlarımız, haz. Selçuk Demirbağ, (Tercüman 1001 Temel Eser). Said Halim Paşa, "İslâm'da Teşkilat-1 Siyasiye”, trc. Mehmet Akif, Sebilürreşad, 20/ 496, 17.

${ }^{32}$ Elmalılı Hamdi, Müslümanlık Mâni-i Terakki Değil, Zâmin-i Terakkidir”, Sebilürreşad, 21/44-45, 187.

33 Elmalılı Hamid, "Müslümanlık Mâni-i Terakkî Değil, Zâmin-i Terakkidîr", Türkiye'de İslâmcılık Düşüncesi-1, haz. İsmail Kara, (İstanbul: Dergâh Yayınları, 2011), 482.

${ }^{34}$ Akseki, "İslâm ve Terakkî", 869.
} 


\section{Mekke Ulemasının Sultan II. Abdülhamid'e Gönderdiği Mektuba Göre Osmanlı Devleti'nin İnkırazının Sebepleri}

İlk bölümde ele alındığı üzere Osmanlı uleması ve aydınlarının bir kısmı devletin inkırazının sebebinin dinden değil, aksine dinin Müslümanlar tarafından anlaşılmaması olduğunu ifade etmişlerdi. Bu minval üzere düşüncelerini serdeden Dersaadet'teki ulema gibi, Osmanlı Devleti'nin çeşitli vilayetlerinde yaşayan ulema ve aydın grupları da konuyla ilgili değerlendirmeler yapmıştır. Devletin inkırazı ve bu inkıraz karşısında dinî yaşayışın önemine dair fikirlerini Sultan II. Abdülhamid'e ulaştıran kesimlerden birisi de Mekke ulemasıdır. 29 Ramazân 1296 (16 Eylül 1879) tarihinde Sultan II. Abdülhamid'e gelen varakada Mekke uleması dinî yaşayıştaki bozulma ve bunun devletin inkırazına etkisine dair fikirlerini beyan etmiştir. Padişaha övgü ile başlayan ${ }^{35}$ bu belgede Osmanlı Devleti'nin, Batı karşısındaki geri çekilişinin sebepleri ele alınmıştır. Varakayı mühürleyen ulema Sultan II. Abdülhamid'e, Allah (c.c.)'nin kendisini hilafet makamına seçmesinin sebebini, onun İslâm dininin ahkâmını icrâ etmesi ve Müslümanların yanlışlarını düzeltmesi için olduğunu hatırlatmıştır. Bunun için gerekli olan zekâ, güç ve iktidarın Allah'ın bir ihsanı olarak kendisine verildiğini belirtmiştir. Mekke uleması “...envâr-ı ilâhiye olan ziyâ-dâr ve müstenîr olan basîret-i humâyûna hafî değildir ki esbâb-ı mûcibe zâ'il olmadıkça bir maraz zâ'il olan ve mu'âlece te'sîr etmez" diyerek, söz konusu Müslümanların İslâm'a sahip çıktıkları sürece güçten düşmeyeceklerini ifade etmiştir. ${ }^{36}$ Oysa İslâm dünyasının şimdiki durumu oldukça kötüdür. Ulemanın anlatımıyla durum şöyledir:

"Ulemâ-yı kirâm hazerâtı hâdise-i hâzıra sekiz yüz seneden beri emsali görülmemiş bir felâket olup küffâr dîn-i İslâm'ı esâsından tahrîb etmek ve emvâl-i müslimîni nehb ü gârât eylemek istiyorlar ve kadın-erkek büyük-küçük hep Müslümânları katl ediyorlar ve kurâ-yı İslâm'ı sekenesiyle beraber ateşlere yaklyorlar ve Müslümânları taht-ı hükûmetlerine alıp bizler ile muhârebâtta siper yaptyorlar ve nice nice cevr u zulm icrâsında bulunuyorlar ...",37

Ulemaya göre, İslâm beldelerinin bu perişan durumu karşısında bütün Müslümanların cihâda hazırlık yapması, halkın bu yolda düzene konulması ve teşvik edilmesi farzdır. Ümmetin perişan hali karşısında ne yapılması gerektiği, çarenin ne olduğu, Müslümanların tekrar ayağa kalkması için nasıl bir yol izlemesi gerektiği sorularını soran Mekke uleması, İslâm dünyasının içinde bulunduğu durum hakkındaki tespitler yapar. Ulemaya göre İslâm dininin dûçâr olduğu acı durum, İslâm memleketlerinde ortaya çıkan zaaf, Batı karşısındaki haysiyet kırıcı gerileyiş, düşmanların hücumu ve bütün yaşanan sıkıntıların sebebi ilahi emirlerin yani İslâm'ın önemsenmemesinden kaynaklanmaktadır. ${ }^{38}$ Mekke ulemasının bu tasavvuru, Doksan Üç Harbi olarak bilinen ve Osmanlı Devleti'nin başkentini dahi tehdit eden 1877-1878 Osmanlı Rus Savaş'ından hemen sonra, muhtemelen ulemadan biri tarafından yazılmış olan belgede de dile getirilmiştir. Söz konusu bu savaşta Osmanlı Devleti'nin Ruslar karşısında ağır bir yenilgi almasının sebebi olarak toplumun dinden uzaklaşmış olması tespiti

\footnotetext{
35 Tevfikat-1 Samedâniyesi istikâmet-saz-1 umûr olan vâcib-i te'âlâya hamd ü senâ ve Peygamber-i zî-şân hazretlerine subh u mesâ arz-1 salavât ü tehâyâ ve hazret-i Emîru'l-mü’minîn pâdişâh-1 a'zam ve hâkân-1 mu'azzam Gâzî Abdülhamîd Hân eyyedallâhu bihi'l-İslâme cânib-i seniyyü'l-cevânib-i şâhânelerine îfâ-y1 lâzıme-i du'â kılındıktan sonra huzûr-1 fahamet-nüşûr-1 şehin-şâhîlerine arz olunur ki...

${ }^{36}$ BOA., YPRK., MK., 1/16, g. 2.

${ }^{37}$ BOA., YPRK., MK., $1 / 16$, g. 2.

${ }^{38}$ BOA., YPRK., MK., 1/16, g. 2.
} 
yapılmıştır. ${ }^{39}$ Dinî alandaki yozlaşmanın, siyasî güçsüzlüğe sebep olduğu tasavvuru esasında daha eskiye dayanmaktadır. XVII. yüzyılda devletin buhran içinde olduğu bir dönemde Kadızadeliler, yaşananların esasen birer bela ve musibet olduğunu ifade ediyorlardı. ${ }^{40}$ Böylece başa gelen kötülüklerin sebebinin dinî yaşantıdaki yozlaşma olduğu tespitini yapıyorlardı. Ancak İslam dünyasında özellikle on dokuzuncu yüzyılda ikinci bir grup fen (tecrübi) bilimlerinin terakki için yegâne kurtarıcı olduğu görüşünde birleşiyorlardı. Fuat Sezgin' in ifadesiyle bu iki düşünce arasında kalanlar, “...çoğu kere, donuklaşma sebeplerini İslâm toplumundaki bir müessese veya müesseselerin bozulmasına, geri kalmışlı̆̆ına veya içlerine yabancı unsurlardan bir şeyin karışmasına... " bağlıyorlardı. ${ }^{41}$

Kötü gidişat hakkında yazılan birçok risale ve rapor, toplumsal ve kurumsal bir yozlaşmanın var olduğu tespitini yaptıktan sonra, devletin kanun-1 kadime geri dönüşle kurtarılacağına işaret etmekteydi. ${ }^{42}$ Kanun-1 kadim zaaf içine düşmüş Müslüman toplumun özlem duyduğu parlak dönemlerdi. Esasında bu bir hayalet gibi devlet adamlarının ve toplumun arasında geziniyordu. Ancak kanun-1 kadime dönüşün nasıl gerçekleşeceğiyle ilgili ayrıntılı çalışmalar devlet adamları nezdinde yok gibiydi. Devletin eski dönemlerde olduğu gibi sadece kendi gücü ile ayakta kalamayacağının anlaşıldığı on dokuz ve yirminci yüzyıllarda dahi gerek devlet adamları gerekse ulema arasında İslam dünyasındaki kötü gidişatın sebeplerini ayrıntılarıyla tespit eden, parlak bir dönem geçiren İslam müesseselerinin nasıl oluyorda çöküşe geçtiğini açıklayan kimseler yok gibidir. Esasında "İslâm medeniyetindeki donukluğu genel bir tahlile tabi tuttuğumuzda bunu tarihte her milletin başına gelen tarihî vakıa olarak..."43 kabul etmek gerekmektedir. Nitekim geçmişe şöyle bir göz atıldığında yukarıda bahsi geçen düşüncelerin sadece Müslüman aydınlara has bir durum olmadığı görülür. Avrupa'da reform hareketleri döneminde benzer yaklaşımlar Hristiyan dünyası içinde geçerliydi. Örneğin Martin Luther, Türklerin (Müslümanların) Hristiyan dünyasının günahları sebebiyle, Tanrı tarafından gönderilmiş bir ceza olduğunu düşünüyordu. Ona göre de Katolik kilisesindeki yozlaşma ve insanların dinden uzaklaşması buna sebepti. ${ }^{44}$ Örneklerden de anlaşıldığı üzere dinsel kimliğin toplumsal ve siyasal olayları betimlediği bir dönemde, inkıraza duçar olan medeniyetin mensupları dini yozlaşma ve siyasi inkıraz arasında paralellik kuruyorlardı.

Mekke uleması da Osmanlı Devleti'nin inkırazı ile dinsel yaşam arasında paralellik kurmuş ve dindeki bozulmanın devletin gerilemesindeki asıl amil olduğunu beyan etmiştir. Ulemaya göre toplum dinî kurallara karşı isyan içindedir. İslâm'ın ahlak kurallarına aykırı yaşama konusunda fazlasıyla istekli görüntüsüyle Müslümanlar, şer’i kuralları bütünüyle ihmal etmiştir. Frenk adetlerini taklit edenler, bu halleriyle iftihar eder bir tavır içinde olmakla birlikte, peygamberin sünnetine karşı tamamen yabancılaşmaktadır. Batıcı telakki havas ve avam arasında gittikçe yaygınlaşıyor

\footnotetext{
${ }^{39}$ BOA. Y. EE. 78/81. M. Şemseddin (Günaltay): “Terakkimize mâni olan İslâmiyet değil bize öğretilen Müslümanlıktır.” diyordu. Kara, Din ile Modernleşme Arasında, 83.

${ }^{40}$ Ali Fuat Bilkan, Fakihlerin ve Sofuların Kavgası 17. Yüzyılda Kadızâdeliler ve Sivâsîler, (İstanbul: İletişim Yayınları, 2017), 62.

${ }^{41}$ Fuat Sezgin, “İslam Medeniyeti’nin Donuklaşmasının Sebepleri Meselesi”, Çorum İhlahiyat Fakültesi Dergisi, trc. Dursun Hazer, 2002/2, 296.

42 Enveri, "Nizam-1 Cedîde Dâ'ir (Islahat) Meyânında Virilen Lâyihadır", III. Selim'e Sunulan Islahat Layihaları, haz. Ergin Çağman, Kitabevi Yayınları, İstanbul 2010, 3-5

${ }^{43}$ Sezgin, "İslam Medeniyeti’nin Donuklaşmasının Sebepleri Meselesi”, 303.

${ }^{44}$ Önder Canveren, "Martin Luther'in İslâm ve Türkler Hakkındaki Değerlendirmeleri”, Dumlupınar Üniversitesi Sosyal Bilimler Dergisi, 42, (Kütahya 2014), 156-157.
} 
olmasına karşı, bunlara karşı herhangi bir zecrî uygulama da yoktur. ${ }^{45}$ Sahih bir medeniyetin varlığını semavi bir din ve üstün bir ahlakla temellendiren ulema, Batılı yaşam biçiminin taklit edilmesinin devletin inkırazını durduracak bir çare olduğu fikrine şiddetle karşıdır. Aslında Mızraklı İlmihâl'de geçen "Bir kimse kâfir işi güzeldir diye itikat etse küfürdür" ibaresi, İslâm ulemasının dünya tasavvuruna ve İslâm dairesi dışındaki kültür ve medeniyetin taklit edilmesine bakışını değerlendirmek açısından önemli bir örnektir. ${ }^{46}$ Çünkü İslâm'ın son semavî dindir ve mevcut semavi dinler içerisinde İslâm dini kadar terakkinin önünü açan ahlakî, içtimầ, idarî ve siyasî esaslara istinat etmiş bir din yoktur. ${ }^{47}$ Bundan dolayı da Batı'nın gülüyle dikeniyle taklit edilmesi gerektiğini söyleyenlerin istekleri gayrı meşrudur. Medeniyet ancak bir dine inanan insanlar tarafından ortaya çıkarılabilir. Dinsiz topluluklar bir medeniyet ortaya koyamayacakları gibi, dinî, mezhebi, itikadı olmayan herhangi bir şahıs kendisini behîmiyetten kurtaramaz, ${ }^{48}$ dolayısıyla böyle bir kişinin veya topluluğun üstün bir ahlak ortaya koyması da beklenemez. Bu noktada Mekke uleması da İslâm dinin esaslarına sahip çıkarak devletin inkırazdan kurtarılabileceğini belirtir. Mekke ulemasına göre Müslümanlar arasında yaygınlaşan gayr-i İslâmî adetler devleti felakete sürüklemektedir. Ulema devleti çöküşe götüren bu gibi adetlerin bazıları şöyle sıralıyor:

"Makâmât-ı mübâreke ziyâreti sûretinde kadınların açık saçık dolaşmasına bakılmayıp ĭgmâz edilmek/ Zevci ve mahremi bulunan kadınların çarşı ve pazarda alış-verişte bulunmalarına müsâ'ade olunmak/ Kadınlar ă̆laşarak bağırarak cenâze arkasında gitmek/ Meyyit için mâtem âdet ve bid'atlerini icrâ etmek/ Labirlerden kefen sirkat olunmak/ Sakal kazılıp biylklar uzatılmak kerâmet izhârıyla beraber bî-namâzlık ve irtikâbâtta bulunmak/ Müslümân kadınlar Hıristiyan hânelerinde hizmetçi olmak/ Evlâd tarafindan pedere talebeden üstâda dervîşândan şeyhe vâcibe-i itâ'at ve ri'âyet terk olunmak/Sahâbe-i kirâm efendilerimiz hakkında itâle-i lisân olunmak/ Umûr-ı siyâsiyede müsâmahat ve rehâvet kılınmak", ${ }^{49}$

Ulemanın belirttiği bu adetler, İslam toplumunun dönüşümünü ifade etmekle birlikte, bu durumun devletin inkırazında oynadığı rolün ne olduğu büyük bir soru işaretidir. Bahsedilen konuların toplumsal bir yozlaşmayı işaret etmesine ek olarak, siyasi gerilemenin mi yoksa bu tür bir yozlaşmanın mı önce başladığını da tespit etmek gerekmektedir. Ulemanın bahsi geçen durumlar karşısında temel isteği, Frenk adetlerini yaşayan ve topluma taşıyanlara karşı devlet eliyle tedbir alınması ve gerekirse bunlara karşı cezai işlemlerin yapılmasıdır. Batılı yaşam biçiminin taklit edenlere karşı ulemanın bu sert tavrı, Osmanlı basın ve mecmualarına da yansımıştır. Sebilürreşad'da yayınlanan "Kadınlarımızı ve Kızlarımızı Kolumuza Takmakla Terakki Edemeyiz" başlıklı yazıda Avrupa'daki yaşam biçimi kısmi bir biçimde ele alınmış ve şiddetli bir şekilde eleştirilmiştir. Esasında bu eleştiri Osmanlı Devleti'nin terakki edebilmesi için

\footnotetext{
${ }^{45}$ BOA., YPRK., MK., 1/16, g. 2

${ }^{46}$ Mizraklı İlmihal, haz. İsmail Kara, (İstanbul: Dergâh Yayınları, 2017), 96.

47 Şeyhülislâm Musa Kazım, "Medeniyet Din İlişkisi”" Türkiye'de İslâmcılık Düşüncesi-1, haz. İsmail Kara, (İstanbul: Dergâh Yayınları, 2011), 119.

${ }^{48}$ Şeyhülislâm Musa Kazım, "Medeniyet Din İlişkisi”, 119.

49 Maddelerin yazılı olduğu sayfalardan biri kanımızca eksiktir. Çünkü maddeler sıralanırken diğer sayfada aniden konu değişmiştir. Yapılan araştırmalarda görüntüye rastlanılmamıştır. BOA., YPRK., MK., $1 / 16$, g. 3 .
} 
Bat1 gibi olması gerektiğini düşünenlere yöneltilmiştir. ${ }^{50}$ Devletin içinde bulunduğu durum dolayısıyla belgeye imza atan Mekke ulemasının tavrıyla, Dersaadet'teki Osmanlı aydınlarının/ulemanın bir kısmının tavrının örtüşmesi gayet doğaldır. Burada sorulması gereken önemli bir soru, ulemanın sert ve keskin bir tavırla Batı kültürüne karşı olmasının sebepleri arasında eski ile yeninin (mekteb-medrese) çatışmasının bir rolü olup olmadığıdır? Yoksa gerçekten de devletin gerilemesinin ana sebebinin "ahlakî yozlaşma" olduğuna inanılması mıdır? Bu soruya kesin bir cevap vermek elbette zordur. Ancak bir değerler çatışmasının olduğu açıktır. Bundan dolayı ulemanın varakada belirtilen bir çizgide olması gayet doğaldır.

Mekke uleması devletin kötü gidişatının sorumluluğunu sadece topluma yüklememiş, problemler karşısında yetersiz kalan, çare üretemeyen ulemâ ve ümerânın da gerek toplumsal yozlaşmadan ve gerekse İslâm ülkelerinin kötü durumdan sorumlu olduğunu ifade etmiştir:

“...ulemâ ve ümerâ bakmıyorlar hâlbuki her kangl kavimde mâ'siyet râygân olur ise dûçâr-ı nikâl-i vebâl ve karîn-i sû-i hâl olurlar fahr-l kâ'inât aleyhi efdalü't-tahiyyât efendimiz buyurmuşlardır ki ma siyet gizli olması takdîrinde mazarratı yalnızca sâhibine âid olup i'lân-ı me 'âsî umuma muzırrdır ve dahi buyurmuşlardır ki emru bi'l-ma'rûf ve nehyü ani'l-münker ya icrâ olunur ve yâhûd Hakk te 'âlâ sizlere eşirrâyı musallat eder ve sonra sulehâ du'â eder de Hakk te 'âlâ kabûl etmez ve dîn ü devlete hâsıl olan hâl ve dünyâ ve âhiretçe nümâyân olan âsâr-l vebâl şerî'at-i garrâ ahkâmının terkini kolay add etmekten neş'et etmiştir,"51

Mektuptaki ifadelerden de anlaşılacağ 1 üzere hangi toplum olursa olsun isyan normal bir hal aldığında, o toplumun büyük bir azaba duçar olması yakındır. Şeriata aykırı davranışlar kişiler tarafından gizli olarak yapıldığında ahlaki bozulma sadece sahibine ait iken, topluma açık olması kötülüklerin halk arsında yayılması sonucunu doğuracaktır ki Osmanlı inkırazına sebep olan başlıca amil de ahlaki yozlaşmanın kamusal alanda yaygın bir hal almasıdır. ${ }^{52}$ Mekke ulemasına göre iyiliği emredip kötülükten nehy etmesi gereken kimseler, görevini yerine getirmediği/getiremediği bir toplumda bozulma kaçınılmazdır. Toplumsal bozulmanın nihayetinde devletin işleyişini bozacağı konusunda da ulema arasında mutabakat vardır. Dersaadet'teki aydın ve ulemandan bazı kimseler de -Ali Suavi gibi- devletin inkırazı karşısında medrese ehlinin çözüm üretemediğini ifade etmiş ve ulemaya eleştiriler yöneltmiştir. Ancak bu eleştiriler ulemanın bilgisine yönelik olmayıp daha çok aksiyoner olmamalarıyla yani fiili çözümler üretememeleriyle ilgilidir. Tanzimat dönemi içerisinde birçok kıymetli ulema olmasına rağmen, Ahmet Cevdet Paşa gibi Osmanlı Devleti'nin inkırazının sebeplerini araştıranların olmaması bu eleştirilerin asıl konusudur. Çünkü kökeni asırlara uzanan bu kurumun mensupları, devletin çözülmeye başladığı bir dönemde siyasî, malî ve toplumsal sorunlara yönelik çareler üretme noktasında yetersiz kalmışlardır. Bu göreceli bir bakış açısı olmakla birlikte, o günden günümüze ulaşan çok sayıda raporun olmaması bunun kanıtı niteliğindedir. Esasında ulema sınıfının bahsi geçen konularla

50 Din kaydından azade kalmak için Avrupa'yı dolaşmayı tavsiye eden cibilliyeti bozuk sefihler, Avrupa'da tahsil eden şu necib İslâm gencinin mütalaat-1 dindaranelerine acaba ne diyecekler? Sebüllürreşad, 279.

${ }^{51}$ BOA., YPRK., MK., $1 / 16$, s. 1.

${ }^{52}$ BOA., YPRK., MK., 1/16, s. 1. 
ilgili daha aktif olduğu dönemler söz konusudur. Mesela Şeyhülislam Ebusuud'un tımar topraklarının bölünmezliğiyle ilgili vermiş olduğu fetvanın siyasî, malî ve toplumsal boyutları söz konusudur. ${ }^{53} \mathrm{Bu}$ bakımdan fetva incelendiğinde, devleti ve toplumu ilgilendiren bir konuda, Ebusuud'un çözüm önerdiği anlaşılmaktadır. Modernleşme dönemi ulemasından beklenen de bahsi geçen örnekte ve Ahmet Cevdet Paşa'nın Mecelle'yi hazırlama örneğinde olduğu gibi daha aksiyoner bir tavır içinde olmasıdır. Medrese sistemini dolayısıyla ulemayı eleştirenler, kurumun zamanın ihtiyaçlarına cevap vermemesi konusunda, devletin bu kurumu ihmal etmiş olmasının da etkisi olduğu belirtilmiştir. ${ }^{54}$

Ancak çok temel bazı problemler dururken ulemanın tali konular üzerinde enerjisini harcadığg da görülmektedir. Örneğin Roderch H. Davinson'un, Charles Eliot'tan aktardığına göre telgrafın caminin ne kadar yakınından gitmesi gerektiğini tartışan âlimler vard1. Yine 1880'ler veya 1890'larda basılan bir risalede telgraf dahil birçok yenilik kınanıyordu. Risalede bu gibi yeniliklerin kafirler tarafından günahkâr insanları yoldan çıkarmak için yayıldığı belirtiliyordu. ${ }^{55} \mathrm{Bu}$ spesifik örnek elbette ulemanın geneline teşmil edilemez. Keza ulemanın dünyayı anlamada yetersiz olduğu da söylenemez. Ancak ulemanın Osmanlı Devleti'nin Batı karşısında sürekli olarak geri çekildiği bir dönemde, güçlü bir şekilde çözüm üretmediği söylenebilir.

Mekke ulemasına göre devletin içine düşmüş olduğu aciz durumun sebebi dindeki noksanlık değil bilakis bu durum, dinin Müslümanlar tarafından yetirince anlaşılamamasından, zamana göre tefsir edilememesinden kaynaklanmaktadır. Eğer İslâm ahlakı yeniden topluma egemen olur ve Müslümanlar bu doğrultuda çalışırsa geçmişlerinde olduğu gibi yeniden büyük bir medeniyeti ihya etmelerinin önünde bir engel yoktur. Mekke uleması düşüncelerini Kur'an'dan Rum/41, Rad/11 ve Muhammed/7 surelerini örnek vererek temellendirmiştir. ${ }^{56}$ Çeşitli örneklerle Osmanlı Devleti'nin inkırazının sebeplerini açıklayan ve bu açıklamalarını dinî metinlerle temellendiren Mekke uleması, Sultan II. Abdülhamid'e "..me'âsîden ictinâb ile ve evâmir-i ilâhiyeye imtisâl ile beraber nusret-i dîne çalışır iseniz size nusret-i ilâhiye hâsıl olur" ${ }^{57}$ diyerek eğer kendisi Allah'ın dinine hizmet ederse, Allah (c.c) da kendisine yardım edeceğini ifade etmiştir. Aksi durumda olacakları ise ulema şöyle ifade etmiştir:

“...yoğusa emr-i ber-aks olup sebâtsızlık ile makhûr olursanız ve pâdişâh-ı İslâm hazretleri kutb-ı merkez-i umûr ve imâm-ı a'zam-ı

\footnotetext{
${ }^{53}$ Halil İnalcık Osmanlı İmparatorluğu'nun Ekonomik ve Sosyal Tarihi, 1, (İstanbul: Eren Yayıncılık, 2009), 193.

${ }^{54}$ Gencer, İslâm'da Modernleşme Serüveni, 502-503.

${ }^{55}$ Roderich H. Davinson, "Osmanlı İmparatorluğu'na Elektirikli Telgrafın Girişi”, OTAM, trc. Durdu Mehmet Burak, 14, (Ankara: 2003), 358.

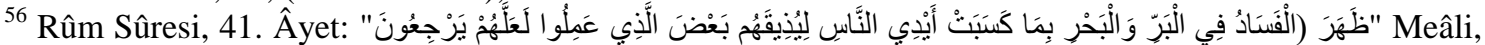
Elmalılı Hamdi Yazır: "İnsanların ellerinin kesbi ile karada ve denizde fesad meydan aldı, yaptıklarının

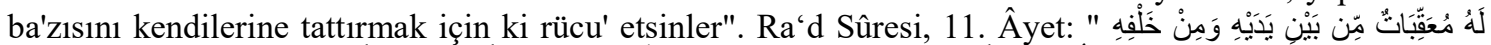

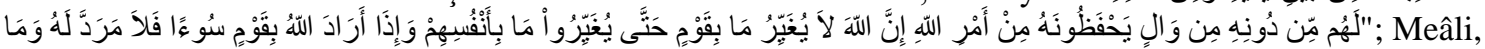
Elmalılı Hamdi Yazır: "Her biri için önünden ve arkasından ta'kıb eden Melâike vardır, onu Allahın emrinden dolayı gözetirler. Her halde Allah, bir kavme verdiğini onlar nefislerindekini bozmadıkça bozmaz, bir kavme de Allah, bir kötülük irade buyurdu mu artık onun reddine çare bulunmaz, öyle ya onlar için ondan başka bir vâli yok"

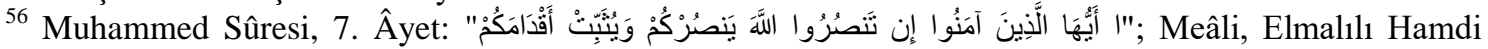
Yazır: "Ey o bütün iyman edenler! Eğer siz Allaha yardım ederseniz o size nusrat verir ve ayaklarınızı kaydırmaz". BOA., YPRK., MK., 1/16, 1.

${ }^{57}$ BOA., YPRK., MK., $1 / 16,1$.
} 
cumhûr-ı millet-i İslâmiye'dir bilâd-ı İslâmiye'de zuhûr eden münkerât ve bid'atleri huzûr-ı pâdişâhîye arz etmek lâzımdır tâ ki îcâbını icrâ buyursunlar şimdi ise artık me 'âsî ve münkerât güneş gibi zâhirdir ve muharremât her yerde raygân olmuştur bunlar ise belây da'vet eder ve İslâm'ı muzmahil ve perîşân eyler a'dâ-yı dîn musallat olur âsâr-l ittifâk kalmayıp yüreklerde nifâk çoğalır küçük büyüğe itâ'at etmez olur halkın arasında dahi fitne zuhûr ederek yă̆mur yă̆maz feyz $u$ bereket olmaz çünkü muharremâtın en büyüğü şirk ve evâmir-i ilâhiyeyi terk olduğu ma 'lûmdur",58

$\mathrm{Bu}$ uyarılardan sonra Mekke uleması göndermiş olduğu mektupta kötü gidişatın durdurulması için "Neyh ü vaz olunması gelen münkerât" yani dince uygun görülmeyen ve yasaklanması gereken şeyleri açıklamıştır. Mekke ulemasına göre gerek toplumsal çözülmenin ve gerekse devletin inkırazının önüne geçmek için şu kötü fiilleri düzeltilmesi gerekmektedir:

"Zarûret-i şer'iyye yoğ iken mekâbir ve mesâcidi hedm ü tahrîb ile sokak yapmak/Evkâf musakkafâtının sûret-i şer 'iyyede olmayarak bey" ü istibdâline cesâret olunmak/ Müslümân olan zencî ve Çerkeslerin bey" ü şirâ'sını tecvîz etmek/ Siyâh Arablart hâdim yapmak/ Müslümân mahallesinde kilise inşâ etmek ve buna yardım olunmak/ Kur'ân-ı Şerîf tilâvet olunurken duhân içilip hürmetsizlik olunmak/ Cevâmi "ve mesâcid-i şerîfeye küçük çocuklarl idhâl ile hürmetsizlik göstermek ve nezafet ve tahâretlerine dikkat olunmamak/ Ulemâ ve sulehâyı tahkîr etmek/Haham ve keşişleri ta'zîm ile zarûret-i şer 'iyye yoğ iken bunlarl Müslümânlara takdîm ettirmek/ Müslümân olan esîrleri küffâra satmak/ Cizye alınmamak ve ehl-i zimmet olanlara şerâit zimmeti icrâ ettirmemek/ Ehl-i zimmete te 'addî ve zulm etmek /Müslümân memleketinde küffârdan hâkim bulunmak/ Me'mûrînin fukarâ mâlında gözü olup tama' etmek/ Me'mûrînin harekât-ı vâkı 'alarını teftîs ve taharrî etmemek/ Müstehakk olmayanlara rütbe ve mansıb tevcîh etmek/ Hiyânet ve fenâlıklarl tebeyyün eden me'mûrîni istihdâm etmek/ Tiyatro çalgl çengi gibi âlât ve esbâb-l lehv bulunmak/ Kadınların müskirât isti'mâl eylemesi ve çocuklara içirilmesi gibi fenâlıklar olmak/ Hammâmlarda ve sâ'ir mahallerde inkişâf-ı avretten ihtirâz olunmayıp tesettüre tamâmen ri'âyet olunmamak/ Çarşılarda ve her yerde kadınlar açık gezmek/ Kîle ve terâzî ve endâzelere dikkat olunmamak/ Makberelerde binâ ihdâs olunmak" ${ }^{\text {,59 }}$

Toplumsal bozulmanın sebeplerini belirten ve yirmi üç maddeden oluşan metin incelendiğinde, maddelerin genelinde toplumda yaygınlık kazanan gayr-i İslâmî hususlar üzerinde durulduğu anlaşılır. Devletin genel işleyişi ile ilgili bir iki noktaya temas edilmişse de bunlar o günün Osmanlı Devleti'nin sorunlarını tanımlamaktan ve bu sorunlara çözüm yolları önermekten uzaktır. Dersaadet'te Osmanlı Devleti'nin zamanın şartlarına göre terakkisi mevzusunun yoğun olarak gündemde olduğu ve İslâm dininin terakkiye mâni olup olmadığının tartışıldığı bir dönemde Mekke ulemasının Sultan'a göndermiş olduğu bu varakada konuya değinmemiş olması dikkati celp

\footnotetext{
${ }^{58}$ BOA., YPRK., MK., 1/16, 1-2.

${ }^{59}$ BOA., YPRK., MK., 1/16, 2-4.
} 
etmektedir. Ayrıca bulundukları konum gereği eğitim hususunu gündeme getirmeleri beklenen ulemanın bu konu üzerinden de yeterince durmadığı görülmektedir. Binâenaleyh mektubun bu yönüyle devletin kötü gidişatına çareler üretme noktasında yetersiz olduğu söylenebilir ve bu yönden eleştirilebilir. Ancak unutulmaması gereken nokta Mekke ulemasının bu mektupla daha çok sosyal bozulmanın üzerinde durmasıdır ve bu bozulmanın önüne geçilmesinin öncelikleri olmasıdır. Ayrıca burada göz önünde bulundurulması elzem olan bir başka konu da varakanın Doksan Üç Harbi'nden hemen sonra gönderilmiş olmasıdır. Bu savaşta alınan yenilgi ve devletin içine düşmüş olduğu tehlikeli durum ulemanın tavrını etkilemiştir.

Gerileyişin kaynağı dini yozlaşma olunca, çarenin de dinin yeniden ihya edilmesinde aranması şarttır. İslâm medeniyetinin kuruluş ve yükseliş dönemlerinde itici bir güç olan din nasıl oluyor da devletin inkırazına sebep oluyordu. Said Halim Paşa'nın ifadeleriyle: "Ĕger aynı sebepler artık aynı neticeleri ortaya çıkarmıyor ve doğurmuyorsa bu kesinlikle şundan ileri geliyor: Müslüman milletler kendi İslâmî vazifelerini, eskisi gibi çok iyi bir şekilde idrak edememek ve yerine getirememek kabiliyetsizliğine düşmüşlerdir. "60 Hâlbuki Müslümanlar eğer dinlerini zamanın ruhuna uygun tefsir etseler, İslâm onları geçmişteki şanlı tarihleri seviyesine yeniden çıkaracaktır. ${ }^{61}$ Mekke ulemasının da belirttiği gibi mesele dinin, modern zamana hitap edememesiyle ilgili değildir, onun takipçileri tarafından yeterince anlaşılamamasıdır. Milaslı İsmail Hakkı'da yazmış olduğu Başka Milletler Ne İçin Terakki Ediyor; Biz Ne İçin Terakki Edemiyoruz isimli makalesinde bu konuyu irdelemiştir. Makalesinde terakki edememenin nedenlerini, İslâm ile mi, Türklükle mi, çalışmamayla mı, ahlaki bozulmayla $\mathrm{m} 1$ ilgilidir diye sorular sorar ve söz konusu bunların hiçbirinin Osmanlıların geri kalmalarına sebep olmadığını söyler. Çünkü Batı karşısındaki gerileyiş sadece Osmanlılara has olmayıp, İslâm âleminin geneliyle ilgilidir. Bütün bir İslâm âleminin tembel, dinden uzaklaşmış, ahlaki olarak yozlaşmış olması beklenemez. O zaman problemin kaynağını daha farklı bir noktada aramak gerekiyordu. ${ }^{62}$ Milaslı İsmail'in bu noktada kendisinden çok önce konuyla ilgili düşüncelerini serdetmiş olan Mekke ulemasından ayrıldığı görülmektedir. Esasında Mekke ulemasının konu hakkında ki fikri, makalenin genelinde işlenmiştir. Bundan dolayı yeniden bu konuya işaret etmek yersizdir. Şunu da ifade etmek gerekiyor ki Mekke ulemasının varakada ifade ettiği fikirleri, esasında Osmanlı ulemasının tamamının olmasa da genelinin ortak düşüncesidir.

Mekke uleması devletin inkırazdan kurtulması için bazı öneriler de ortaya koymuştur. Ulemaya göre kötü gidişatın durdurulması için Beytü'l-mâl'ın ihrâcâtını şerî'at-i garrâya göre yani İslâm'ın büyük, nurlu kurallarıyla yapmalı, ulemâ ve ümeraya yönelik olarak devlet tarafından çıkarılan hususi emirlerle, halka İslâm'ın doğru bir şekilde anlatılması sağlanmalıdır. Zira cehâlet özellikle dinî hususlarda halk arsında yaygındır. $\mathrm{Bu}$ durum iyileştirilmezse bütün bir tolumun mahvına sebep olacaktır. ${ }^{63}$

\footnotetext{
${ }^{60}$ Said Halim Paşa, “İslâm'da Siyasi Teşkilat”, Türkiye’de İslâmcılık Düşüncesi-1, haz. İsmail Kara, (İstanbul: Dergâh, 2011), 153

61 Mehmet Kaan Çelen, "Said Halim Paşa Üzerine Notlar: İslâm âleminin Gerileme Sebepleri ve Türklerin İslâm Tasavvruru”, Asia Minor Studies, 9/5, 2017, 16.

${ }^{62}$ Milaslı İsmail Hakkı, "Başka Milletler Ne için Terakki Ediyorlar; Biz Ne İçin Terakki Edemiyoruz", Sebilürreşad, (11 Şevval 1337), 86-88.

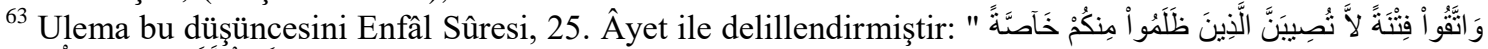
"وَاعَلَكُو أ أنََّّ اللَّ شَدِيدُ الْعِقَابِ yalnız zulmedenlere dokunmakla kalmaz ve bilin ki Allah'ın 1kabı şiddetlidir". BOA., YPRK., MK., 1/16, g. 2 .
} 
Ulema, Osmanlı Devleti'nin inkırazının sebebini dinî yozlaşmaya bağlarken, tam tersi devleti çöküntüden kurtaracak şeyin dini dünyevî alandan dışlayıp sadece uhrevî konulara hasretmekle mümkün olacağını söyleyenler de vardı. M. Zekeriya (Sertel) tarafından kaleme alından ve Büyük Mecmua'da yayınlanan Asrî Cemiyetlerde Dinin Mevkii isimli makale bu düşünceyi açık bir şekilde dile getiriliyordu. ${ }^{64}$ Büyük Mecmuadaki bu yazıyı Milaslı İsmail Hakkı'da gündemine almış ve Din ve Asrilik makalesiyle cevap vermiştir. Makalesinde Büyük Mecmua'da yayınlanan yazının iddialarını ayrıntılı bir şekilde ele alan Milaslı Hakkı asrilik mevzusunun yanlış anlaşıldığını belirterek asrî olmayı şöyle tanımlamıştır: “... asrilik ve asrî fert veya asrî millet olmak demek müterakki milletlerin ilimlerini, marifetlerini, hünerlerini, zanaatların, makbul ve makul terbiye ve adetlerini alarak maddi ve manevi salah ve liyakat sahibi olmak demektir." 65 Milaslı Hakkı çoğu İslâm münevveri/uleması gibi sadece teknik mevzularda değil makul koşullarda Batılıların terbiye sistemleri ve adetlerinden de yararlanılabileceğini belirterek yeni bir duruşu ortaya koymuştur. Milaslıya göre terakki etmiş zamanın milletlerinin seviyesine çıkabilmek için Osmanlıların, dinini, ahlâkını, ananesini, muhafaza etmek ve gerek fert ve gerek millet ve gerek devlet her ahlâk-ı ilmiyeye tamamen muvafik olan din-i İslâm'ın tahtı velayetinde bulunmakla müftehir olmak gerekir. Bu da müterakki milletlerinin her türlü hüner ve marifetlerini kemaliyle edinmek sayesinde olabilir. ${ }^{66}$

Tunuslu âlim Abdülaziz Çaviş'in, Sebülürreşad'da Mehmet Akif'in tercümesiyle yayınlanmış olan makaleleri bu mevzuyu derinlemesine ele almıştır. Mekke uleması gibi Tunuslu âlimin düşüncesine göre de din, İslâm aleminin gerileyişinin sebebi değildir. Ancak Müslümanların dinî yaşantılarının bir sonucu olarak Müslüman memleketler Batı'nın istilasına uğruyordu. Ona göre, mağlup olan milletlerin galip olanları taklit etmesinde bir beis yoktur. Nitekim Roma'nın istila ettiği memleketlerin hepsi de bu imparatorluğu, hayatın bütün alanlarında taklide koyuldular. Keza Avrupalılar Endülüs Müslümanlarını uzunca bir dönem taklit ettiler. Ancak bu taklit ediş onların kendi medeniyetlerinin ruhlarını, ananelerini ve kökenlerini unutmalarına sebep olmadı. Müslümanların Batı karşısındaki geri çekilişi de benzer bir hadiseye sebep oldu. Ancak Müslümanlar bu noktada İngilizlerin Roma medeniyetinden yararlandığı veya Avrupalıların Endülüs medeniyetinden yararlandığı gibi bir yol takip etmedi. Onlar zevahire kapılarak, daha önce de değinildiği gibi yaşam tarzının birçok alanında başta Fransızlar olmak üzere diğer Batılı milletleri taklit etti. Çaviş’e göre bu taklitçilik Müslüman okumuş yazmış kesimin -özellikle Avrupa'da tahsil görenlerinİslâm dünyasındaki marazların sebebini dinde aramasına sebep oldu. Ancak bu yolu takip edenler Fransız diline, kültürüne, tarihine aşina oldukları kadar kendi tarihlerine, kültürlerine, dillerine aşina değildi. ${ }^{67}$ Dolayısıyla meftunu oldukları bir medeniyete bakarak kendi milletleri için kurtuluş yolu bulmaları zordu. Buradan hareketle Osmanlı Devleti'nin farklı coğrafyalarındaki âlimlerin ortak bir düşüncede birleştiğini söylemek mümkündür. $\mathrm{O}$ da devletin yeniden ihyasının, ancak dinin ihyasıyla yaşanabileceği hususudur. ${ }^{68}$

\footnotetext{
${ }^{64}$ Bkz. M. Zekeriya, “Asrî Cemiyetlerde Dinin Mevkii”, Büyük Mecmua, 4, 51-52.

${ }^{65}$ Milaslı İsmail Hakkı, "Din ve Asrilik”, Sebilürreşad, (16 Recep 1337), 170-171.

${ }^{66}$ Milaslı İsmail Hakkı, "Din ve Asrilik”, Sebilürreşad, (16 Recep 1337), 170-171.

${ }^{67}$ Abdülaziz Çaviş, “Alem-i İslâm Hastalıkları ve Çareleri”, Sebilürreşad, (8 Zilhicce 1334), 145-148.

68 Gazetede yayınlanan ve dokuz makaleden oluşan Alem-i Íslâm Hastalıkları ve Çareleri başlıklı yazılarda Çaviş bu konuları derinlemesine irdelemiştir. Her ne kadar Çaviş’in görüşleri bu bağlamda üzerinde daha çok durulmayı hakkediyorsa da makalenin sınırlarını bir hayli zorlamaktadır.
} 
Çalışmanın konusu olan varakada Mekke uleması, İslâm dünyasını temsil eden aydınların/ulemanın bir yandan Avrupa emperyalizmine karşı seslerini yükseltirken diğer taraftan onu ilerlemenin yurdu olarak betimleme ${ }^{69}$ tezadına değinmemiştir. Böyle bir değerlendirme esasında konunun daha da açıklığa kavuşmasını sağlaya bilirdi. Osmanlı modernleşmesi her ne kadar askerî alandaki yenilgilerin bir sonucu olarak değerlendirilse de özellikle Sultan II. Mahmud dönemi sonrasında gerek devlet politikası düzeyinde gerekse aydınlar nezdinde bilinçli bir tercihle Avrupa medeniyetin nüvesi olarak görülmüş ve takip edilmiştir. Ulemanın Dersaadet'te ve genel anlamda bütün bir Osmanlı coğrafyasında büyük bir güce haiz olmasına rağmen ${ }^{70}$, devletin terakkisi noktasında yönlendirici ol(a)mamış olması üzerinde durulması gereken bir konudur. Bu anlamda sorgulanması gereken önemli problemlerden birisi de ulemanın devleti yıkıntıdan kurtarmak amacıyla, batı kaynaklı ilerleme telakkisi ve yine oradan gelen kanunlar karşısında nasıl davrandığıdır. Bu kısa metinde bunun tahlil edilmesi oldukça zordur. Çalışmanın konusu olan varakada da buna yönelik ciddi çıkarsamalara rastlanmamiştır.

\section{SONUÇ}

Osmanlı Devleti, oluşturduğu sosyal, siyasal ve askerî düzen sayesinde uzun yıllar Avrupa'ya ihtiyaç duymadan kendi problemleriyle baş edebilen bir sistem kurdu. Bununla birlikte Osmanlı devlet adamları Batı'dan yararlanmayı da ihmal etmedi. Ancak bu yararlanma belli alanlara münhasır ve seçiciydi. Binaenaleyh Osmanlılar Batı'yı kuşatıcı bir şekilde gözlemleme ve yararlanma hususuyla yeterince ilgilenmedi. Özellikle Sanayi Devrimi sonrasında Batı karşısındaki gerileyişin ana sebeplerinden biri de bu tavırdı. Batı karşısında üstünlüğün yitirilmeye başlanması, ilk başta ve ciddi olarak harp sahalarında hissedildi. Osmanlılar zaman içerisinde teknik, eğitim, fabrikalaşma ve ticaret alanlarında da Batı'nın kendilerinden hayli ileri düzeye geldiğini anladı. Ancak tedbirler alınıncaya kadar bu durum devletin klasik düzen dinamiklerini ciddi şekilde sarstı. Toprak kayıplarıyla başlayan bu süreç, ilk başta askerî alanda ki yenilikleri gündeme getirecekse de, Batı tarzı modernleşme zaman içerisinde sosyal, siyasal ve ekonomik alanların tümüne yayıldı. Batı tarzı yenileşme veya Batı'yı taklit etme meselesi bir problem olarak gerek Osmanlı devlet adamlarını ve gerekse Osmanlı aydın/ulema sınıfının zihinlerini meşgul etti. Her ne kadar bahsi geçen kesimler temelde devleti yok olmaktan kurtarmaya dönük çabalar içerisinde olsalar da ileri sürdükleri fikirler ve Batı'yı telakki biçimleri birbirlerinden farklıydı. Bu noktada bir kesim Batı'nın her şeyinden yararlanılmasını savunurken, başka bir kesim sadece teknik boyutuyla Batı'dan yararlanma taraftarıydı. Batı'nın teknik boyutuyla takip edilmesi gerektiğini ifade edenlerin başında İslâmcı düşünceyi benimsemiş Osmanlı aydınları gelmekteydi. Bu düşünürler, millî kalarak kalkınmadan yanaydı.

Osmanlı aydın/ulema sınıfı her ne kadar Batı'yı teknik boyutuyla takip etmeyi İslâmî olarak temellendiriyor olsalar da kötü gidişatın en önemli sebeplerinden birinin dinin yozlaşmasından veya daha hafif bir ifadeyle Müslümanların dinlerini yeterince tanımamasından kaynaklandığını ifade ediyordu. Bu çerçevede Dersaadet'deki Osmanlı aydını/uleması düşüncelerini çeşitli mecmualarda dile getiriyordu. Bunun dişında makalenin konusu olan Mekke uleması da uzun bir mektupla, Sultan II. Abdülhamid'e

\footnotetext{
${ }^{69}$ Ussama Makdisi, “Osmanlı Oryantalizmi”, Oryantalizm Tartışma Metinleri, ed. Aytaç Yıldız, (Ankara: Doğu Batı Yayınları), 2007, 273.

${ }^{70}$ Oğuz Adanır, Osmanlı ve Avrupalılar, (Ankara Doğu Batı Yayınları, 2013), 160-161.
} 
devletin kötü gidişatının sebeplerinin Müslümanların günaha batmasından ileri geldiğini anlatıyordu. Mektubun gönderildiği tarih dikkate alındığına 1877-1878 Osmanlı Rus Harbi'nden sonraki yıllara denk gelmesi, üzerinde durulması gereken bir noktadır. Her ne kadar Rusların yapmış olduğu zulümlere belgede kısmen değinilmiş ve Müslümanların Rus hücumu karşısında cihada koşması gerektiği belirtilmişse de Ruslar karşısında alınan acı yenilginin sebepleri üzerinde ayrıntılı bir şekilde durulmamıştır. Ulemanın genel eğilimi dinî yozlaşma ile devletin inkırazı arsında paralellik kurmaktır. İslâm dünyasının önemli bir bölümünün Batı'nın sömürgesi durumuna düşmesi, Batı karşısındaki gerileyişin ve Müslümanların esir konuma gelmesi gibi birçok hususun sebebi bu çerçevede ele alınmıştır. Mekke ulemasının Batı'yı toplum olarak taklit etmenin, devleti yıkıma götüreceği hususundaki düşünceleri, Dersaadet'de kendilerinden önce veya sonra bu konuya eğilmiş olan Osmanlı devlet adamları, aydın ve ulema kesiminin fikirleriyle benzerlik arz etmekle beraber, Mekke ulemasının soruna yaklaşım tarzı kapsayıcı değildir. Ulema bahsi geçen varakada, Batı'daki bilimsel ilerlemenin kaynağına, Osmanlı Devleti'nin, kültür ve medeniyet düzeyinde olmasa da teknik anlamda Batı'yı taklit edip edemeyeceği hususuna açıklık getirmemiştir. Ayrıca ulema, Osmanlı Devleti'nin kötü gidişatıyla ilgili genel bir tespitte bulunmuş, çözüm yolu olarak da yine genel esasları ortaya koymakla yetinmiştir. Mekke ulemasının problemlere yönelik ayrıntılı reçetesi olmayınca, mektup devletin problemlerine çare olmaktan uzak bir belge olarak kalmıştır. Son olarak geçmişten günümüze uzun tarihi bir süreci kapsayan 1slahat veya modernleşme meselesinin Osmanlı Devleti'ndeki ulema tarafından nasıl algılandığının ve devletin yeniden terakkisi için ne gibi çözüm yollarının olduğunun bilinmesi, Türk yenileşmesinin zaaflarının ve güçlü yönlerinin ortaya konması açısından önemlidir. Ulemanın inkıraz karşısında neden ciddi ıslahat projeleriyle ortaya çık(a)madığına yönelik çalışmaların çoğalması, günümüzde medeniyet kaynaklı birçok tartışmaya 1 ş1k tutacak ve günümüz problemlerinin kökenlerinin anlaşılmasına katkı sağlayacaktır.

\section{KAYNAKÇA}

BOA., YPRK., $M K$., $1 / 16$.

BOA. Y. EE. $78 / 81$.

Abdülaziz Çaviş. “Âlem-i İslâm Hastalıkları ve Çareleri”. Sebilürreşad, (8 Zilhicce 1334), 145-148.

Adanır, Oğuz. Osmanlı ve Avrupalılar. Ankara: Doğu Batı Yayınları, 2013.

Ahmet Cevdet Paşa. Tezakir. haz. Cavid Baysun, 1, Ankara: Türk Tarih Kurumu Yayınevi, 1953.

Akseki, Ahmet Hamdi. “İslâm ve Terakkî” Türkiye'de İslâmcılık Düşüncesi-2. İstanbul: Dergâh, 2011.

Aydin, Mithat. "Namık Kemal'de "Terakki" ve "Maarif” Düşüncesi. Ankara Üniversitesi Dil, Tarih, Coğrafya Fakültesi Dergisi, 53/2, 452-477.

Babanzade Ahmed Naim. "İslâmiyet'in Esasları Mâzî ve Hali”. Sebilürreşad, 12/284, 373.

Babanzade Ahmed Naim. “İslâm'ın Dünü ve Bugünü”. Türkiye'de İslâmcllık Düşüncesi-1, haz. İsmail Kara, İstanbul: Dergâh, 2011. 
Berkes, Niyazi. Türkiye'de Çă̆daşlaşma. haz. Ahmet Kuyaş, İstanbul: Yapı Kredi Yayınları, 2002.

Bein, Ahmet. Osmanlı Uleması ve Türkiye Cumhuriyeti. İstanbul: Kitap Yayınevi, 2013.

Bilkan, Ali Fuat. Fakihlerin ve Sofuların Kavgası 17. Yüzyılda Kadıâdeliler ve Sivâsîler. İstanbul: İletişim Yayınları, 2017.

Canveren, Önder. "Martin Luther'in İslâm ve Türkler Hakkındaki Değerlendirmeleri”. Dumlupinar Üniversitesi Sosyal Bilimler Dergisi, 42, (Kütahya 2014), 151163.

Cündioğlu, Dücane. "Ernest Renan ve "reddiyeler" Bağlamında İslâm-Bilim Tartışmalarına Bibliyografik Bir Katkı". Divan, 1/ 2, (İstanbul 1996), 1-94.

Çatma, Bahattin. "Abdullah Cevdet'e İctihadî Bir Bakış: Vefatının Ardından Hakkında Yazılanlar Üzerinden Bir Portre Denemesi”. Geçmişten Günümüze Malatya Uluslararası Sempozyumu Kent, Kültür ve Kimlik, (Malatya, 14-16 Nisan 2016), 1095-1109.

Çetin, Nurullah. “Ziya Paşa”. Tanzimat Edebiyatı, Koordinatör: İsmail Parlatır, Ankara: Akçağ Yayınları, 2006.

Çelen, Mehmet Kaan. "Said Halim Paşa Üzerine Notlar: İslâm Âleminin Gerileme Sebepleri ve Türklerin İslâm Tasavvruru”. Asia Minor Studies, 9/ 5, (2017).

Edward Said. Oryantalizm. trc. Nezih Uzel, İstanbul: İrfan Yayınları, 1998.

Ersoy, Mehmet Akif. “Süleymaniye Kürsüsünden”. Safahat, haz. M. Ertuğrul Düzdağ, İstanbul: İz Yayınc1lık, 1991.

Edip, Eşref. Mehmet Akif. haz. Fahrettin Gün, İstanbul: Beyan Yayınları, 2011.

Elmalı1ı Hamdi. "Müslümanlık Mâni-i Terakki Değil, Zâmin-i Terakkidir". Sebilürreşad, 21/44-45.

Elmalılı Hamdi. "Müslümanlık Mâni-i Terakkî Değil, Zâmin-i Terakkidîr”. Türkiye’de İslâmcılık Düşüncesi-1, haz. İsmail Kara, İstanbul: Dergâh Yayınları, 2011.

Enveri. "Nizam-1 Cedîde Dâ'ir (Islahat) Meyânında Virilen Lâyihadır". III. Selim'e Sunulan Islahat Layihaları, haz. Ergin Çağman, İstanbul: Kitabevi Yayınları, 2010.

Enginün, İnci. Yeni Türk Edebiyatı Tanzimat'tan Cumhuriyet'e (1839-1923). İstanbul: Dergâh Yayınları, 2010.

Davinson, Roderich H.. "Osmanlı İmparatorluğu'na Elektirikli Telgrafın Girişi”. OTAM, trc. Durdu Mehmet Burak, 14, (2003), 347-386.

Sezgin, Fuat. “İslam Medeniyeti’nin Donuklaşmasının Sebepleri Meselesi”, Çorum Illahiyat Fakültesi Dergisi, trc. Dursun Hazer), 2002/2, 295-303.

Gencer, Bedri. İslâm'da Modernleşme 1839-1939. Ankara Doğu Batı Yayınları, 2012.

Findley, Cartrer V.. Osmanlı Imparatorluğu'nda Bürokratik Reform Babıâli, 17891922. trc. Ercan Ertürk, İstanbul: Tarih Vakfi Yurt Yayınları, 2014.

Hikmet, Hasan. "Taklid Seyyiesi”. Sebilürreşad, 21, 212-213.

İnalcik, Halil. Osmanlı Imparatorluğu'nun Ekonomik ve Sosyal Tarihi. İstanbul: Eren Yayınc1lık, 2009. 
İskilipli Atıf Hoca. "Batıyı Taklit Etmek ve Medeniyet Meseleleri”. Türkiye'de İslâmcılık Düşüncesi, haz. İsmail Kara, İstanbul: Dergâh, 2011.

Kara, İsmail. Din ile Modernleşme Arasında Çağdaş Türk Düşüncesinin Meseleleri. İstanbul: Dergâh Yayınları, 2014.

Kara, Hidayet. “İkdamcı Cevdet'in İsviçre Notları Işı̆̆ında Osmanlı Aydınının Batı Algisı". History Studies, 10/7, (2018), 164-184.

Karpat, Kemal H.. İslâm'ın Siyasallaşması. İstanbul: İstanbul Bilgi Üniversitesi Yayınlar1, 2010.

Kolcu, Ali İhsan. Tanzimat Edebiyatı I. Erzurum: Salkım Söğüt Yayınevi, 2008.

Makdisi, Ussama. “Osmanlı Oryantalizmi”, Oryantalizm Tartışma Metinleri, nşr. Aytaç Yıldız, Ankara: Doğu Batı Yayınları, 2007.

Mızraklı İlmihal. haz. İsmail Kara, İstanbul: Dergâh Yayınları, 2017.

Milası İsmail Hakkı. "Başka Milletler Ne için Terakki Ediyorlar; Biz Ne İçin Terakki Edemiyoruz". Sebilürreşad, (11 Şevval 1337), 86-88.

Milaslı İsmail Hakk1. “Din ve Asrilik”. Sebilürreşad, (16 Recep 1337), 170-171.

M. Zekeriya. “Asrî Cemiyetlerde Dinin Mevkii”. Büyük Местиa, 4/51-52.

Okay, Orhan. Batılılaşma Devri Türk Edebiyatı. İstanbul: Dergâh Yayınları, 2016.

Ortaylı, İlber. "Tanzimat Adamı ve Tanzimat Toplumu”. Tanzimat, Değişim Sürecinde Osmanlı Imparatorluğu, Haz. Halil İnalcık-Mehmet Seyidanlığlu, Ankara: Phoenix Yayınları, 2006, 301-334.

Öztürk, Osman. "Osmanlılarda Tanzimat Sonrası Yapılan Hukukî Çalışmalar ve Mecelle-î Ahkâm-1 Adliye". Osmanlı, 6, Ankara: Yeni Türkiye Yayınları, 2001, 504-518.

Said Halim Paşa. "İslâm Âleminin Gerilik Sebepleri Üzerine Deneme". Buhranlarımız, haz. Selçuk Demirbağ, Tercüman 1001 Temel Eser, ty.

Said Halim Paşa. "İslâm Âleminin Gerileme Sebepleri Üzerine Bir Deneme". Türkiye'de İslâmcılık Düşüncesi-1. haz. İsmail Kara, İstanbul: Dergâh, 2011.

Said Halim Paşa. Bütün Eserleri. haz. N. Ahmet Özalp, İstanbul: Büyüyen Ay Yayınlar1, 2015.

Said Halim Paşa. "Meşrutiyet”. Buhranlarımız, haz. Selçuk Demirbağ, Tercüman 1001 Temel Eser, ty.

Said Halim Paşa. “İslâm'da Teşkilat-1 Siyasiye”. (Çev. Mehmet Akif), Sebilürreşad, 20/496, 17.

Said Halim Paşa. “İslâm'da Siyasi Teşkilat”, Türkiye'de İslâmcılık Düşüncesi-1. haz. İsmail Kara, İstanbul Dergâh, 2011.

Seyyid Bey. "İçtihat ve Taklit”, Türkiye'de İslâmcılık Düşüncesi-1. haz. İsmail Kara, İstanbul Dergâh, 2011.

Şeyhülislâm Musa Kazım. "Medeniyet Din İlişkisi” Türkiye’de İslâmcılık Düşüncesi-1. haz. İsmail Kara, İstanbul: Dergâh Yayınları, 2011. 
Tunaya, Tarık Zafer. Türkiye’nin Siyasî Hayatında Batılılaşma Hareketler. İstanbul: İstanbul Bilgi Üniversitesi Yayınları, 2010.

Tunç, Mustafa Şekip. Terakki Fikri. haz. Osman Bahadır, İstanbul: Anahtar Yayınları, 2005.

Yakut, Esra. Şeyhülislâmlık Yenileşme Döneminde Devlet ve Din. İstanbul: Kitap Yayınevi, 2014.

Uçman, Abdullah. "Namık Kemal”. Tanzimat Edebiyatı, Koordinatör: İsmail Parlatır, Ankara: Akçă̆Yayınları, 2006.

Ziya Paşa. Tercî-i Bend, Terkibi-i Bend. haz. Hüseyin Yorulmaz, İstanbul: Çıdam Yayınlar1, 1992, 119-122.

https://vahadergisi.wordpress.com/2007/02/17/batiyi-seven-ziya-pasa-baticilardansikayetci/ (Erişim Tarihi: 19.09.2018)

http://mehmetakifarastirmalari.com/2016/02/28/suleymaniye-kursusunde/

(Erişim tarihi: 29. 04. 01. 2019).

Ekler

Ek: 1

\section{Mekke-i Mükerreme Ulemâsı Tarafından Memhûr Arabiyyü'l-ibâre Varakanın Tercümesi}

Tevfikat-ı Samedâniyesi istikâmet-saz-ı umûr olan vâcib-i te'âlâya hamd ü senâ ve Peygamber-i zîl-şân hazretlerine subh u mesâ arz-ı salavât ü tehâyâ ve hazret-i Emîru'lmü'minîn pâdişâh-ı a'zam ve hâkân-ı mu'azzam Gâzî Abdülhamîd Hân eyyedallâhu bihi'l-İslâme cânib-i seniyyü'l-cevânib-i şâhânelerine îfâ-yı lâzıme-i du'â kulındıktan sonra huzûr-l fahamet-nüşûr-l şehin-şâhîlerine arz olunur ki

Hakk te 'âlâ hazretleri zât-ı hilâfet-penâhîyi taht-ı âlî-i hilâfette mekîn ü intihâb ve ta yîn buyurması dîn-i mübîn-i İslâm'ın ahkâmını icrâ ve Müslümânların (...) takvîm buyurması ve mevhibe-i ilâhiye olan kuvvet-i akl ü zekâ ve kemâl-i miknet ve iktidâr-l şâhânelerini bu yolda isti 'mâl eylemesi içindir envâr-ı ilâhiye olan ziyâ-dâr ve müstenîr olan basîret-i humâyûna hafì değildir ki esbâb-ı mûcibe zâ'il olmadıkça bir maraz zầil olan ve mu'âlece te'sîr etmez bizler ise dîn-i mübîn-i Muhammedî'nin dîçâr olduğu ahvâl-i mü'ellimeyi ve memâlik-i İslâmiye'ye târî olan za'f ve Tenezzülü ve a'dânın hücûmu ve cümlenin mesâ'ib ve gumûmu hep evâmir-i ilâhiyenin mühimmsenilmemesinden ve isyân ve fücûra inhimâkten ve i 'lân-ı fisk u isyândan hâsıl olmuş görünüyor o emr-i şer 'iyye bütün bütün ihmâl olunmuştur âdât-l frengâneye mutâba'at halka medâr-ı iftihâr olmuştur sünnet-i seniyye-i Peygamberî terk olunuyor me'âsî gittikçe çoğallyor sigâr $u$ kibâr ve havâss $u$ avâmm arasında fisk $u$ isyân âdet olmuştur bununla beraber men' ü zecr olunmuyorlar ve ulemâ ve ümerâ bakmıyorlar hâlbuki her kangl kavimde ma siyet raygân olur ise dûçâr-ı nikâl-i vebâl ve karîn-i sû-i hâl olurlar fahr-ı kâ'inât aleyhi efdalü't-tahiyyât efendimiz buyurmuşlardır ki ma siyet gizli olması takdîrinde mazarratı yalnızca sâhibine âid olup i'lân-ı me'âsî umuma muzırrdır ve dahi buyurmuşlardır ki emru bi'l-ma 'rûf ve nehyü ani'l-münker ya icrâ olunur ve yâhûd Hakk te 'âlâ sizlere eşirrâyı musallat eder ve sonra sulehâ du'â eder de Hakk te 'âlâ kabûl etmez ve dîn ü devlete hâsll olan hâl ve dünyâ ve âhiretçe nümâyân olan âsâr-l vebâl şerî'at-i garrâ ahkâmının terkini kolay add etmekten neş'et etmiştir 
Kur'ân-ı Kerîm'de "zahara'l-fesâdü fîll-berri ve'l-bahri bi-mâ kesebet eydi'n-nâsi liyüzîkahum ba'za'llezî amilû le 'allehum yerci'ûn" etmesinden denizde ve karada kesad zuhûr etmiştir ki ettiklerinin birazına(?) ya'nî seyyi'esine uğrayıp da şâyed ric'at ve nedâmet gösterirler" ve dahi "innallâhe lâ yugayyiru mâ bi-kavmin hattâ yugayyirû mâ bi-enfüsihim" ${ }^{72}$ ve dahi "İn tensurullâhe

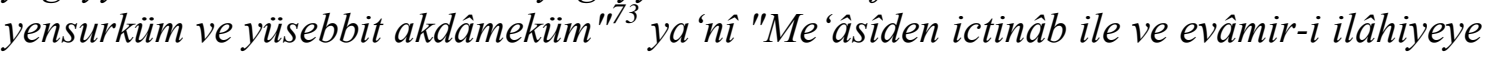
imtisâl ile beraber nusret-i dîne çalışır iseniz size nusret-i ilâhiye hâsıl olur yoğusa emr$i$ ber-aks olup sebâtsızlık ile makhûr olursanız ve pâdişâh-ı İslâm hazretkeri kutb-ı merkez-i umûr ve imâm-ı a'zam-ı cumhûr-ı millet-i İslâmiye'dir bilâd-ı İslâmiye'de zuhûr eden münkerât ve bid'atleri huzûr-ı pâdişâhîye arz etmek lâzımdır tâ ki îcâbını icrâ buyursunlar şimdi ise artık me âsî ve münkerât güneş gibi zâhirdir ve muharremât her yerde raygân olmuştur bunlar ise belây da 'vet eder ve İslâm'ı muzmahil ve perîşân eyler a'dâ-yı dîn musallat olur âsâr-ı ittifâk kalmayıp yüreklerde nifâk çoğalır küçük büyüğe itâ'at etmez olur halkın arasında dahi fitne zuhûr ederek yağmur yăgmaz feyz $u$ bereket omaz çünkü muharremâtın en büyüğü şirk ve evâmir-i ilâhiyeyi terk olduğu ma'lûmdur

Nehy ü vaz' olunması lâzım gelen münkerât bunlardır

Ahkâm-ı ilâhiyenin terk ve ihmâliyle hudûd-ı şer 'iyyeyi tecâvüz etmek ve şer 'î olmayan bir takım ahkâma tabi olmak

Emru bi'l-ma 'rûf ve nehyü ani'l-münker vazîfesini ihmâl ile buna ehemmiyet vermemek

Fâ'iz almak emvâl-i eytâma dest-dirâz olmak zinâ livâta müskirât canavar eti yemek

Savm Salât Hacc Zekâtı terk etmek yalancılık iftirâ hased nakl-i kelâm eylemek

Elfâz-ı küfrü telaffuz etmek kâfirleri taklîd eylemek zarûret-i şer 'iyye olmadığı hâlde âdât-ı frengâneye tâbi 'olmak (said halim paşayı ekle)

I'tikâdâtta ef'âlde hey'âtta bid'at

Sünnet-i seniyyeyi terk ile âdât-ı kefereyi sevmek ve iktizâ etmeksizin gasl olunmamak

Eshâm ve sâ'ir düyûn ve mu 'âmelâtta fâ'iz almak

Memâlik-i İslâmiye'de alenen şürb-i hamrı men 'etmemek Ramazân'da bî̀-muhâbâ oruç bozmak

Kadın-erkek birbirleriyle karışmak

Yalan şehâdet etmek hâtıra ri' âyeten şehâdet-i kâzibeden ictinâb olunmamak

Musavver levhaları hânelerinde put gibi ta 'lîk etmek

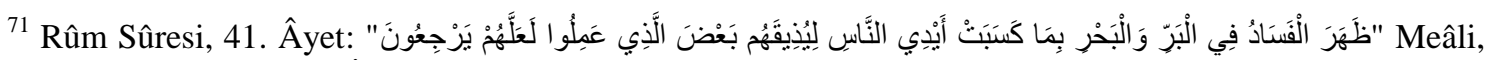
Elmalılı Hamdi Yazır: "İnsanların ellerinin kesbi ile karada ve denizde fesad meydan aldı, yaptıklarının ba'zısını kendilerine tattırmak için ki rücu' etsinler"

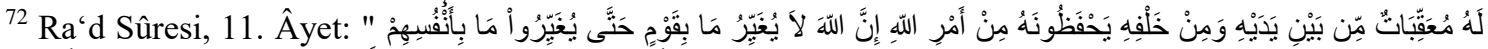

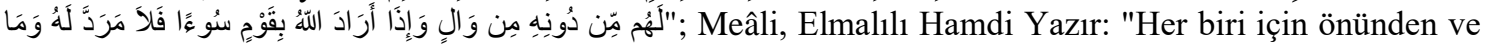
arkasından ta'kıb eden Melâike vardır, onu Allahın emrinden dolayı gözetirler. Her halde Allah, bir kavme verdiğini onlar nefislerindekini bozmadıkça bozmaz, bir kavme de Allah, bir kötülük irade buyurdumu artık onun reddine çare bulunmaz, öyle ya onlar için ondan başka bir vâli yok"

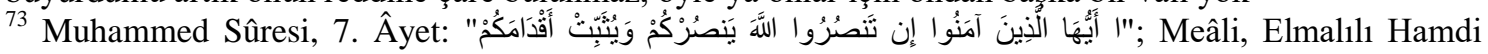
Yazır: "Ey o bütün iyman edenler! Eğer siz Allaha yardım ederseniz o size nusrat verir ve ayaklarınızı kaydırmaz"
} 
Gümrükleri yolsuz almak cizye ve öşr-i şer 'înin istîfâsında halka zulm etmek

Sâhir ve müneccim ve emsâlini men' etmemek

Umûr ve masâlih-i İslâmiye'ye i'tinâ olunmayarak halkın işlerini mecâlis ve aklâm ve mehâkimde sürüncemeye düşürmek bir takım müzevvir ve dînsizlerin sözlerine ısgâ ve iltifât olunup bu makûleleri zecr u redd etmemek

Zarûret-i şer 'iyye yoğ iken mekâbir ve mesâcidi hedm ü tahrîb ile sokak yapmak

Evkâf musakkafâtının sûret-i şer 'iyyede olmayarak bey ' ü istibdâline cesâret olunmak

Müslümân olan zencî ve Çerkeslerin bey' ü şirâ 'sını tecvîz etmek

Siyâh Arabları hâdim yapmak

Müslümân mahallesinde kilise inşâ etmek ve buna yardım olunmak

Kur'ân-ı Şerîf tilâvet olunurken duhân içilip hürmetsizlik olunmak

Cevâmi've mesâcid-i şerîfeye küçük çocuklarl idhâl ile hürmetsizlik göstermek ve nezafet ve tahâretlerine dikkat olunmamak

Ulemâ ve sulehây tahkîr etmek

Haham ve keşişleri ta'zîm ile zarûret-i şer'iyye yoğ iken bunları Müslümânlara takdîm ettirmek

Müslümân olan esîrleri küffâra satmak

Cizye alınmamak ve ehl-i zimmet olanlara şerâit zimmeti icrâ ettirmemek

Ehl-i zimmete te 'addî ve zulm etmek

Müslümân memleketinde küffârdan hâkim bulunmak

Me'mûrînin fukarâ mâlında gözü olup tama' etmek

Me'mûrînin harekât-ı vâkı 'alarını teftîş ve taharrî etmemek

Müstehakk olmayanlara rütbe ve mansıb tevcîh etmek

Hiyânet ve fenâlıkları tebeyyün eden me'mûrîni istihdâm etmek

Tiyatro çalgl çengi gibi âlât ve esbâb-ı lehv bulunmak

Kadınların müskirât isti 'mâl eylemesi ve çocuklara içirilmesi gibi fenâlıklar olmak

Hammâmlarda ve sâ'ir mahallerde inkişâf-ı avretten ihtirâz olunmayıp tesettüre tamâmen ri 'âyet olunmamak

Çarşılarda ve her yerde kadınlar açık gezmek

Kîle ve terâzî ve endâzelere dikkat olunmamak

Makberelerde binâ ihdâs olunmak

Daha vârid olmuştur ki nihâyet hadîs-i şerîfte "Ol hâlde bunlara bir fitne göndereyim ki en akıllıları dûçâr-ı vahlet ve hayret olsun" diye buyrulmuştur bu hâlde ehl-i İslâm için yapılacak en mühimm şey Beytü'l-mâl'ın ihrâcâtını şerî'at-i garrâya tatbîk etmek ve ulemâ ve ümerâya cânib-i devletten evâmir-i mahsûsa tsdârıla mesâcid ve me âbidde halka akâ'id-i İslâmiye'nin tedrîs ve ta 'lim olunması ve ahlâk-ı zemîmenin tefhîmiyle ândan tevakkînin ve tevbe ve istiğfâr ve sâ'ir ahlâk-l memdûhanin tefhîmiyle dahi ânınla tahallî olunmanın vücûbunu herkese anlatarak ibâdât ve mu'âmelât ve nikâh ahkâmının öğretilmesi husûslarına çalışılmaktır zîrâ cehâlet isti 'âb ve ihâta ettiğinden 
bu misilli şeylerde nice Müslümânlar bilmeyerek günah-kâr oluyorlar ukûbet-i ilâhiye cümleyi ihâta eylemesi dahi şâyân-ı havf u ihtirâz olmuştur Hakk te 'âlâ Kur'ân-ı Kerîm'de "ve'ttekû fitneten lâ tusîbenne'llezîne zalemû minküm hâssah"74 buyurmuştur ikâb-ı ilâhî ba'zan ashâb-ı cerâ'ime mahsûs olmayıp hey'et-i umûmiye hakkında cârî olur

$[\text { Sayfa] }]^{75}$

\section{Bihi}

\section{Mekke-i Mükerrreme Ulemâsı Tarafından Arabiyyü'l-ibâre Varaka Tercümesidir}

Ulemâ-yı kirâm hazerâtı hâdise-i hâzıra sekiz yüz seneden beri emsai görülmemiş bir felâket olup küffâr dîn-i İslâm'ı esâsından tahrîb etmek ve emvâl-i müslimîni nehb ü gârât eylemek istiyorlar ve kadın-erkek büyük-küçük hep Müslümânlarl katl ediyorlar ve kurâ-yı İslâm'ı sekenesiyle beraber ateşlere yaklyorlar ve Müslümânları taht-l hükûmetlerine alıp bizler ile muhârebâtta siper yapıyorlar ve nice nice cevr u zulm icrâsında bulunuyorlar kasabât ve kurâdan nicelerini harâb ve ihrâk-l bi'n-nâr edilenler bu hâlde mâlen ve bedenen cümle İslâm'a cihâd vâcib olmaz mı ve halkı buna tertîb ve teşvîk etmek farz değil mi herkeslere bu hâlleri ve işbu vacibat-ı dîniyeyi anlatmamalı midır bu kadar darâ'at ve du'âlar icrâ kılındiğ l hâlde nusret ve eser-i icâbet görülmemiştir bunun esbâbı nedir ve ne yapılmalıdır çâre ve mu'âlece nasıldır ümmet-i müslimeyi helâkten kurtaracak ifâdâtı dirîğ buyurmayın ve lekümü's-sevâb

Hamdele ve tasliyeden sonra Rusya tarafindan icrâ olunan bu mu 'âmelât cümel İslâm'ı mükedder etmiştir ve hâb ü râhattan hepimizi mahrûm bırakmıuştır der-gâh-ı ulûhiyete arz-ı niyâz ve darâ'at olunup ulemâ tarafindan halkı cihâda teşvîk etmek ve bu emr-i vâcibi herkese ta'lîm ve tefhîm eylemek ve herkes sâ'ib ve müstağfir olup cenâb-l Hakk'a niyâz ve Müslümân karındaşlarına mâlen ve bedenen mu 'âvenet ibrâz etmek vacibattan olmuştur böyle olur ise belki ittihâd kılınıp ve ictimâ'-ı külliye(?) hâsıl olur ve cümle İslâm nusret-i dîn-i mübîne çallşlyor ve hertaraftan gazaya koşuşuyor bu ittifâk ve ttihadın husûlü ancak ahkâm-ı şerî'at-i garrâyı icrâ ile ve menhiyâttan intihâ ile ve cümle me 'âsîden ictinâb olunup emru bi'l-ma 'rûf ve nehyü ani'l-münker vazîfesini icrâ ile olur zîrâ hadîs-i şerîfte vârid olmuştur ki "Emru bi'l-ma 'rûf nehyü ani'l-münker vazîfesini ya ilzâm ve icrâ edersiniz ve yâhûd eşirrâ-yı Hakk te 'âlâ sizlere musallat eder ândan sonra sulehâ takımı du 'â etseler de du'âları kabûl olunmaz" bir hadîs-i şerîf daha başka sened-i sahîh ile de rivâyet olunmuştur ve ânda "Hakk te 'âlâ hazretleri böyle emr etti" denilmiştir ve yine hadîs-i şerîfte vârid olmuştur ki "Ne kadar a "mâl-i hasene var ise hepsi cihâda nisbetle deryâdan bir katre gibidir hâlbuki cihâd ile beraber hep a 'mâl-i hasene dahi emru bi'l-ma 'rûf nehyü ani'l-münker yanında yine o nisbettedir" ve yine hadîs-i şerîf-i nebevîde vârid olmuştur ki "Zâhir ve şâyi "olan münkerâtın men 'i husûsunda erbâb-ı iktidâr tarafindan ihmâl gösterilmedikçe seyyi' ât-ı avâmm ile Hakk te âlâ havâssı dûçâr-ı ikâb etmez" bu emr u bi'l-ma 'rûf nehyü ani'lmünker gâyet uzun ve mufassal bir hadîs-i şerîf

Makâmât-ı mübâreke ziyâreti sûretinde kadınların açık saçık dolaşmasına bakılmayıp iğmâz edilmek

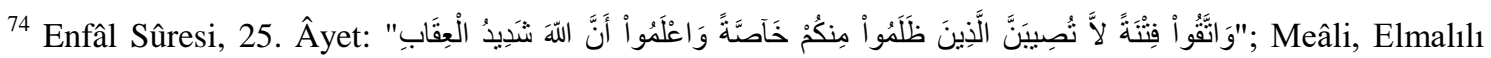
Hamdi Yazır: "Ve öyle bir fitneden sakının ki hiç te içinizden yalnız zulmedenlere dokunmakla kalmaz, ve bilin ki Allahın 1kabı şiddetlidir"

${ }^{75}$ IMG-20180806-WA0003.jpg
} 
Zevci ve mahremi bulunan kadınların çarşı ve pazarda alış-verişte bulunmalarına müsâ'ade olunmak

Kadınlar ă̆laşarak bă̆ırarak cenâze arkasında gitmek

Meyyit için mâtem âdet ve bid 'atlerini icrâ etmek

Labirlerden kefen sirkat olunmak

Sakal kazılıp bıyıklar uzatılmak kerâmet izhârıyla beraber bî-namâzlık ve irtikâbâtta bulunmak

\section{Müslümân kadınlar Hıristiyan hânelerinde hizmetçi olmak}

Evlâd tarafindan pedere talebeden üstâda dervîşândan şeyhe vâcibe-i itâ 'at ve ri 'âyet terk olunmak

Sahâbe-i kirâm efendilerimiz hakkında itâle-i lisân olunmak

\section{Umûr-l siyâsiyede müsâmahat ve rehâvet kılınmak}

İşte bunların mazarratı umûm Müslümânların hakkında dünyâ ve âhiretçe mazarratı umûmîdir ve herkes bunun men'i husûsunda gücünün yettiği mertebece vâki' olacak kusûruna göre mes'ûldür ve bu bâbda cânib-i Emîru'l-mü'minîn ve Imâmü'lmüslimînden men 'ü zecr isti 'mâl ve icrâsı lâzım gelip zîrâ düvel-i sâ'ireye te 'alluk eder husûsâttan değildir bir hâlde bunun farziyeti olup gerek zabtiye ve gerek kuvve-i cünûdiye ve gerek ulemâ ve muhtârân-l mahallât ve kura vâsıtastyla îcâbına bakılmalıdır Allâh "Ve huve'llezî yünezzilü'l-gayse min-ba'di mâ kanetû ve yenşuru rahmetehu" ${ }^{\prime 76}$

\section{Bihi}

Ser-levha-i her-kitâb-ı müstetâb olan hamd ü senâ-yı cenâb-ı Rabbü'l-erbâb ve dîbâce-i minhat ve ni'met-i ilâhiye olan nebiyy-i zî-şâna salavât ve tekrimat-ı bî-hesâb ve tarziye-i âl ü ashâb îfâsından sonra arz olunur ki emru bi'l-ma 'rûf nehyü ani'l-münker kaziyyesi (...) merkez-i devrân-ı umûr olup bi'set-i enbiyâ bu kaziyye-i mühimmeden münba 'is ve ittihâd ve i'tilâf-ı kulûb ile ittifâk ve ictimâ'-ı kelime-i müslimîn husûsuna da bu kaziyye bâ'istir ve ne vakit ki bu kaziyye ilmen ve amelen terk olunur ise nübüvvetin ma 'nâsı kalmaz ve diyânet muzmahil ve dalâlet münteşir olur ve ilmen mahv ü hebâ olarak cihânı fitneler ihâta eder binâenaleyh Kur'ân-ı Kerîm'de Hakk te âlâ ümmet-i Muhammediye'nin esnâsını icrâ buyurduklarında emru bi'l-ma 'rûf ve nehyü ani'l-münker tavsîfiyle yâd buyurmuş Allâh "Küntüm hayra ümmetin uhricet li'n-nâsi te'mürûne bi'l-ma'rûfi ve tenhevne ani'l-münker"77 demiştir ve bunun terkini vasf-ı mezemmet îrâd edip "Kânû lâ yetenâhevne an-münkerin fe'alûhu"78 Ben̂̂ İsrâ'îl'e ma 'îbândan add eylemiştir mefhar-ı mevcûdât efendimiz hadîs-i şerîfinde buyurmuştur ki "İnsânın her sözü kendi aleyhinde olup meğer ki emru bi'l-ma 'rûf nehyü ani'l-münker

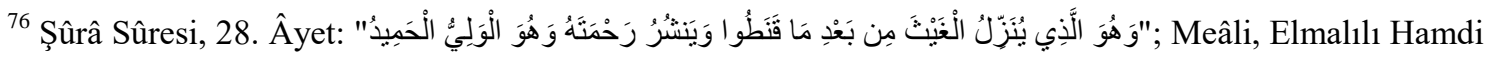
Yazır: "Ve öyledir ki o, ümidi kesmişlerken feyz indirir ve rahmetini neşr eder, o öyle veliy, öyle hamîddir."

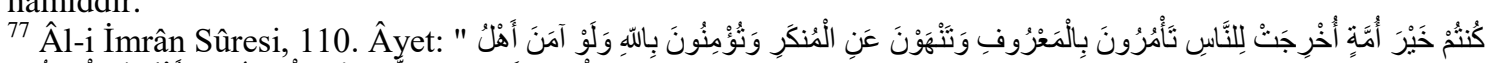

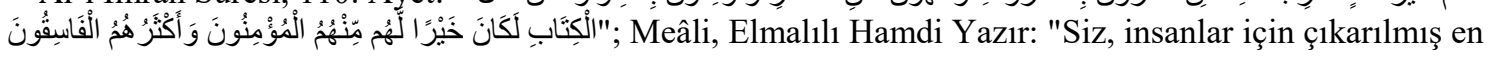
hayırlı bir ümmet olmak üzere vücude geldiniz, ma'rufı emredersiniz, münkerden nehy eylersiniz ve Allaha inanır iman getirirsiniz, Ehli kitab da imana gelse idi elbette haklarında hayırlı olurdu, içlerinden iman edenler varsa da ekserisi dinden çıkmış fasıklardır"

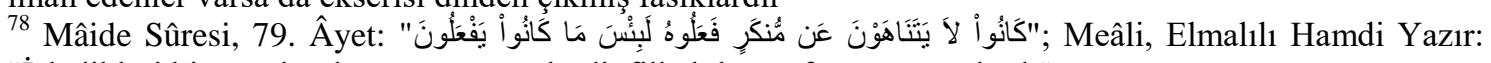
"İşledikleri bir münkerden vaz geçmezlerdi, filhakıka ne fena yapıyorlardı"
} 
ola yâhûd Hakk te "âla ism-i celîlini zikr ede" ve dahi buyurmuşlardır ki "Hakk te âlâ münkerât umûrun beyne'n-nâs zuhûrunda men 'ine kudret-yâb olanlar tarafindan ihmâl olunduğunugörmeyince avâmmın seyyi'âtıyla havâssın hakkında ikâb icrâ buyurmazlar" hattâ o sirada sahâbe-i kirâmdan bir zât "Fahr-ı kâ'inât efendimizden aramızda bunca ehl-i salâh ve takvâ var iken mümkin mü ki ihlâk olunalım" demesiyle "Evet habâset çoğalır ise" buyurmuştur şu hâlde bâlâda münderic olan münkerât ve menhiyâtın ref' ü izâlesine mümkin mertebe çalışmak vâcib oldu ve şu aralık gâyet ehemmiyet kesb eyledi Hakk te 'âlâ zimâm-ı mülkü teslîm ve temlîk edip taht-l âlî-i saltanat-ı İslâmiye'ye cülûsunu mukadder ettiği zât-ı humâyûn-ı pâdişâhî tarafindan bu husûslara icrâ-yı himmet buyrulur ise o da tevfîk ihsân eder evâmir-i seniyye-i pâdişâh $\hat{\imath}$ bütün memâlik-i mahrûseye ısdâr olunup bunun icrâsını emr u fermân buyurmalıdır ve dîn ve milletçe daha her ne muzırr şey var ise izâlesi ve her ne ki mûcib-i salâh-l ümmet ise ânın icrâsı husûslarını cümle ümerâ ve vüzerâya emr u fermân buyrulup ulemâ ve kâffe-i İslâmiyân müttefikan buna çalışmalıdırlar ol hâlde sünnet-i seniyye ihyâ ve bid'at ve dalâlet izâle edilmiş olur ve ittihâd ve ittifâk hâsıl olup şevket-i İslâmiye tezâyüd eder ve hep gördügümüz mesâ'ib mündefi' olarak ehl-i küfr ve tuğyân dûçâr-l hızlân olur feyz ve bereket zuhûr eder taht-ı âlî-i saltanat dahi ilâ-mâ şấallâh sübûtyâfte-i istikrâr ve kuvve-i cünûdiye-i İslâmiye nusret-şi'âr olup herkes de pâdişâh-ı Íslâm efendimize subh u mesâ' du'â ederler

[29 Ramazân sene 1296/4 Eylül 1295/16 Eylül 1879-Salı]

[Mühürler-Soldan başlayarak] ${ }^{79}$

\section{\{1. Sira $\}$}

el-Abdü Muhammed el-Hadarî hâdimü'l-ilmi bi'l-Ezher [Mühür] Abd-i Muhammed elHadarî

el-Fakîr Hasan el-Adevî hâdimü'l-ilmi'ş-şerîf bi'l-Ezher afâ anh [Mühür] Hasan (...)

Abdülhâdî Esârî afâ anh [Mühür] Abdülhâdî (...)

İbrâhîm el-Kutbü'l-Hanefî bi'l-Ezher [Mühür] İbrâhîm el-Kutbü'l-Hanefí

el-Fakîr Mustafâ İzz eş-Şâfi î bi'l-Ezher [Mühür] Mustafâ İzz Râcî Afvi'l-Mu 'izz

el-Fakîr Mustafâ el-Eşrâfí eş-Şâfi 'î [Mühür] Mustafâ el-Eşrâfî eş-Şâfi î̀

el-Fakîru ileyhi te 'âlâ Muhammed el-Bisyûnî(?) (...) afâ anh [Mühür] Muhammed (...)

el-Fakîru ilallâhi te âlâ Yûsuf el-Hanbelî Şeyhu'l-Hanâbileti bi-Mısrl'l-Kâhireti bi'lEzher afâ anh [Mühür] Yûsuf el-Hanbelî

el-Abdü Muhammed el-Binhâvî(?) eş-Şâfi î̀ bil-Ezher afâ anh [Mühür] Abdühu Muhammed el-Binhâvî(?)

\section{\{2. Stra\}}

el-Fakîr Yahyâ Mustafâ el-(...) [Mühür] (...) Yahyâ

el-Fakîru ileyhi te 'âlâ Ahmed el-Cemel eş-Şâfi î̀ es-Sebâ '̂̀(?) afâ anh [Mühür] Ahmed el-Cemel Abdühu'l-Emel Râcî (...)

el-Fakîru ileyhi te âlâ Süleymân el-Abdü'ş-Şarâvî eş-Şâfi '̂̀ afâ anh [Mühür] Süleymân el-Abdü'ş-Şarâvî

\footnotetext{
${ }^{79}$ IMG-20180806-WA0006.jpg
} 
el-Fakîr Abdüllatîf el-Halîl eş-Şâfi 'î afâ anh [Mühür] Abdüllatîf el-Halîl eş-Şâfi 'î

el-Fakîru ileyhi Sübhânehu Abdülvehhâb es-Süyn̂tî el-Hanefî afâ anh [Mühür] Abdülvehhâb es-Süyûtî el-Hanefî

el-Fakîr Süleymân en-Neccâr(?) Sindinehûrî(?) el-Mâlikî bi'l-Ezher afâ anh [Mühür] Süleymân en-Neccâr Abdühu (...) el-Mâlikî

el-Fakîr Hasan Dâvûd el-Mâlikî [Mühür] Hasan Dâvûd

el-Fakîru ileyhi te 'âlâ Muhammed Alî eş-Şamî er-Râfi î̀ el-Hanefî afâ anh [Mühür] Muhammed ibni Alî er-Râfi 'î Kefâ Billâhi (...)

el-Fakîr Mütevellî Alî el-Âsımî el-Hanefỉ bi'l-Ezher afâ anh [Mühür] Mütevellî Alî

\section{\{3. Sira\}}

el-Fakîru ileyhi te 'âlâ Sâlim eş-Şübeynî(?) eş-Şâfi î bi'l-Ezher afâ anh [Mühür] Sâlim eş-Şübeynî(?)

el-Fakîr Alî el-Cenâbenî(?) eş-Şâfi î̀ bi'l-Ezher [Mühür] Alî el-Cenâbenî

el-Fakîru ileyhi te âlâ Alî Merzûk el-Mâlikî e-Adevî bi'l-Ezher afâ anh [Mühür] Ali Ahmed Merzûk el-Adevî

\section{\{4. Sira $\}$}

el-Fakîr Abdülhayy eş-Şâfi î [Mühür] Abdülhayy eş-Şa 'râvî

el-Fakîru ileyhi Sübhânehu Ali el-Muhallâkî(?) el-İzzî(?) eş-Şâfi 'î bi'l-Ezher afâ anh [Mühür] Alî el-İzzî

el-Fakîru ileyhi te 'âlâ Hasan Muhammed el-Kureysenî(?) eş-Şâfi 'î bi'l-Ezher afâ anh [Mühür] Muhammed el-Kureysenî(?) (...) billâhi annî(?)

el-Fakîr Mes 'ûd en-Nablusî el-Hanefí bi'l-Ezher afâ anh [Mühür Okunmuyor]

el-Fakîru ileyhi te 'âlâ Sâlih el-Cibâvîl?) es-Sâmî eş-Şâfi î afâ anh [Mühür] Sâlih eşŞâfi î̀ (...)

el-Fakîr Ahmed Fâyid ez-Zerkânî [Mühür] Ahmed Fâyid

el-Fakîr Alî eş-Şâmî el-Ceyzâvî [Mühür] Alî eş-Şâmî el-Ceyzâvî

el-Fakîru ileyh Muhammed Ebu'l-fasl el-Mâlikî bi'l-Ezher [Mühür Okunmuyor]

el-Fakîru ileyhi te 'âlâ Ahmed el-Mansûrî el-Mâlikî [Mühür] Ahmed el-Mansûrî

el-Fakîru li-rabbihi Ahmed Hanefì el-Mâlikî [Mühür] Ahmed Hanefî

[Sayfa] ${ }^{80}$

\section{\{5. Sira $\}$}

el-Fakîr Hasan el-Fureysî(?) eş-Şarkâvî eş-Şâfi î̀ bi'l-Ezher [Mühür] Hasan (...) elFüreysî(?)

el-Fakîru ileyhi Sübhânehu Mûsâ el-Mersafî(?) eş-Şâfi î̀ bi'l-Ezher afâ anh [Mühür] Abdühu Mûsâ el-Mersafí(?)

el-Fakîru ileyhi Sübhânehu Ahmed el-Mersafi(?) [Mühür Okunmuyor]

\footnotetext{
${ }^{80}$ IMG-20180806-WA0005.jpg
} 
el-Fakîru ileyhi Sübhânehu Muhammed er-Rûmî(?) el-Füyûs(?) el-Mâlikî afâ anh [Mühür] Muhammed er-R̂िmî(?)

el-Fakîru ilallâhi te 'âlâ (...) el-Kiblî(?) el-Mâlikî bi'l-Ezher afâ anh [Mühür] Abdühu (...) $\operatorname{Râ} c \hat{\imath}(\ldots)$

el-Fakîru ilallâhi te 'âlâ Ahmed es-Sabrî el-Mâlikî el-Ezherî afâ anh [Mühür] Ahmed esSabrî

el-Fakîru ileyhi Sübhânehu Rezak(?) Sakar(?) (...) el-Mâlikî bi'l-Ezher [Mühür] Rezak Sakar(?)

el-Fakîru ileyhi te 'âlâ es-Seyyid Ahmed el-Yemenî (...) el-Ezherî Alî [Mühür] es-Seyyid Ahmed bin Muhammed Alî

\section{\{6. Sira $\}$}

el-Fakîru ilallâh Alî Muhammed (...) [Mühür] Alî Muhammed

el-Fakîru ileyhi Sübhânehu Alî eş-Şemûkî(?) el-Mâlikî bi'l-Ezher [Mühür] Alî eş-Şemûkî el-Fakîru ileyhi Sübhânehu ve te 'âlâ Abdullâh eş-Şebruveynî(?) eş-Şâfi 'î bi'l-Ezher afâ anh [Mühür] Abdullâh eş-Şebruveynî(?)

el-Fakîr Ahmed el-Örfì(?) eş-Şâfi 'î bi'l-Ezher [Mühür] Ahmed el-Örfî̀(?)

el-Fakîr İsmâ 'îl el-Hâmidî el-Mâlikî hâdimü'l-ilmi bi'l-Ezher [Mühür Okunmuyor]

el-Fakîr es-Seyyid Ahmed eş-Şerîf el-Mâlikî afâ anh [Mühür] es-Seyyid Ahmed eş-Şerîf

\section{\{7. Sira $\}$}

el-Fakîr Mustafâ el-Kutbü'l-Hanefì [Mühür] Mustafâ el-Kutbü'l-Hanefì

el-Fakîru ileyhi Sübhânehu Sâlih (...) el-İzzî el-Hanefí hâdimü'l-ilmi bi'l-Ezher [Mühür] Sâlih (...) el-ílzzî

el-Fakîru ileyhi te 'âlâ (...) Mustafâ [Mühür] (...) Mustafâ

el-Fakîr Hasan el-Mersagîl(?) eş-Şâfi 'î [Mühür] Hasan el-Mersagîl(?)

el-Fakîr Muhammed et-Tâhir eş-Şarkâvî [Mühür] Muhammed et-Tâhir (...)

\section{\{8. Sira $\}$}

el-Fakîru ilallâhi te âlâ Muhammed el-Hacremî(?) eş-Şarkâvî hâdimü'l-ilmi ve'l-akl(?) bi'l-Ezher [Mühür] Muhammed el-Hacremî

el-Fakîru ilallâh Ebû'l-Hayrân Abdurrahmân el-Kamrâvîl(?) eş-Şâfi î hâdimü'l-ilmi bi'lEzher [Mühür] Abdurrahmân el-Kamrâvî(?)

el-Fakîru ilallâhi te 'âlâ Adevî Zeynü'l-Mersagîl(?) eş-Şâfi î̀ bi'l-Ezher [Mühür] Adevî elMersagîl(?)

el-Fakîru ilallâhi te âlâ Muhammed Ebul-Hâcc Alî hâdimü'l-ilmi bi'l-Ezher [Mühür] Abdühu Muhammed (...) Alî

el-Fakîr Hüseyin Vâlî [Mühür] Hüseyin Vâlî

el-Fakîru ileyhi Sübhânehu es-Seyyid el-Bâcûrî(?) eş-Şâfi 'î afâ anh [Mühür] es-Seyyid el-Bâcûrî(?) İsmâ îl (...) 
el-Fakîr Mahmûd el-Âlim eş-Şâfi î [Mühür] Mahmûd el-Âlim

\section{\{9. Sira\}}

el-Fakîru ileyhi Sübhânehu Muhammed Râzî el-Buharavî el-Hanefî hâdimü'l-ilmi bi'lEzher [Mühür] Muhammed Râzî el-Buharavî

el-Fakîru ileyh (...) Muhammed Râzî el-(...) el-Hanefî [Mühür] Muhammed Râzî (...)

el-Fakîru ileyhi te 'âlâ Ahmed el-Havrî(?) eş-Şâfi 'î afâ anh [Mühür] Ahmed el-Havrî eşŞâfi $\hat{\imath}$

el-Fakîr Ahmed Ömer el-(...) eş-Şâfi 'î afâ anh [Mühür] Ahmed Ömer (...)

el-Fakîru ilallâh Muhammed es-Seyyâhî el-Mâlikî [Mühür] Muhammed es-Seyyâhî

el-Fakîru ilallâh Abdülbirr Ahmed Minnetullâh el-Mâlikî hâdimü'l-ilmi bi'l-Ezher afâ anh [Mühür] Minnetullâh Abdülbirr Ahmed

el-Fakîru ilallâhi te 'âlâ İbrâhîm ez-Zevâhirî hâdimü'l-ilmi bi'l-Ezher [Mühür] İbrâhîm ez-Zevâhirî

\section{$\{10$. Sira $\}$}

el-Fakîru ileyhi Sübhânehu ve tala Yûsuf Alî el-Hanefî bi'l-Ezher afâ anh [Mühür] Abdühu Yûsuf Alî

el-Fakîru ileyhi Sübhânehu Muhammed Ebû'n-Necâ [Mühür] Muhammed Ebû'n-Necâ

el-Fakîru ileyhi Sübhânehu Muhammed (...) Ramazân eş-Şakâvî(?) el-Mâlikî bi'l-Ezher afâ anh [Mühür Okunmuyor]

el-Fakîru ileyh Muhammed İbrâhîm el-Karbâtî eş-Şâfi î̀ afâ anh [Mühür] Muhammed İbrâhîm

el-Fakîru ileyhi Sübhânehu Abdurrahmân es-Sûlî(?) el-Hanefì afâ anh [Mühür] Abdurrahmân en-Nîsî(?)

el-Fakîru ilallâhi te 'âlâ Avz Selâm el-Faşnî(?) eş-Şâfi î [Mühür] Avz Selâm

el-Fakîru ilallâhi te 'âlâ Alî (...) el-Adevî hâdimü'l-ilmi bi'l-Ezher [Mühür] Abdühu Alî (...)

Şeyh Zevâk es-Sa 'âyide(?) bi'l-Ezher afâ anh [Mühür] Ahmed (...)

el-Fakîru ileyhi Sübhânehu Muhammed el-Hüseynî afâ anh [Mühür] Muhammed elHüseynî

el-Fakîru ileyhi Sübhânehu Alî Âmir eş-Şâfi î bi'l-Ezher [Mühür] el-Fakîru ileyhi Sübhânehu Alî Âmir

el-Fakîru ileyhi Sübhânehu Muhammed (...) eş-Şâfi î [Mühür] Muhammed (...)

el-Fakîru ileyhi Sübhânehu Süleymân el-(...) [Mühür] Süleymân (...)

el-Fakîru ileyhi Sübhânehu Abdülmu'tî el-Halîlî el-Hanefî bi'l-Ezher [Mühür] Abdülmu'tî el-Halîlî

el-Fakîru ileyhi Sübhânehu Abdülkâdir el-Cevherî el-(...) bi'l-Ezher [Mühür] Abdülkâdir el-Cevherî (...)

\{11. Stra\}

el-Fakîru ileyhi Sübhânehu Ahmed Ramazân el-(...) el-Hanefî hâdimü'l-ilmi'ş-şerîf bi'l- 
Ezher afâ anh [Mühür] Ahmed Ramazân

el-Fakîr Muhammed Öşrî el-Hanefí bi'l-Ezher afâ anh [Mühür] Muhammed Öşrî

Ketebehu Ahmed er-Rufâ '̂̀ el-Mâlikî [Mühür] Abdühu Ahmed er-Rufâ '̂̀

el-Fakîru ilallâh İbrâhîm Hasan eş-Şâfi î [Mühür] İbrâhîm Hasan

el-Fakîr Afîfî Abdülvehhâb el-Bâcûrî eş-Şâfi î̀ [Mühür] Afîfî Abdülvehhâb el-Bâcûrî

el-Fakîru ileyh Garb es-Sun 'î hâdimü'l-ilmi bi'l-Ezher [Mühür] Garb es-Sun '̂̀

el-Fakîru ileyh Muhammed Fütûh eş-Şâfi 'î [Mühür] Muhammed Fütûh (...)

el-Fakîr Hüseyin es-Seyyid Nühûrî(?) eş-Şâfi î bi'l-Ezher [Mühür] Hüseyin es-Seyyid Nühûrî

Ahmed bin Muhammed (...) [Mühür] Ahmed Muhammed (...)

\{12. Sira\}

el-Fakîru ileyhi Sübhânehu Muhammed İbrâhîm (...) eş-Şâfi î afâ anh [Mühür] Muhammed İbrâhîm (...) eş-Şâfi î̀

el-Fakîru ileyhi Sübhânehu Ahmed Râzî eş-Şarkâvî eş-Şâfi î [Mühür] Ahmed Râzî eşŞarkâvî (...)

el-Fakîr Muhammed (...) hâdimü'l-ilmi [Mühür] Muhammed (...)

el-Fakîru ilallâhi Sübhânehu Muhammed (...) el-Mâlikî afâ anh [Mühür] Muhammed (...) Râcî Afvi'l-Kayyûm

el-Fakîr Hârûn Abdurrezzâk el-Mâlikî bi'l-Ezher [Mühür] Hârûn Abdurrezzâk

el-Fakîru ileyh Muhammed et-Tâcûrî el-Mâlikî afâ anh [Mühür] Muhammed et-Tâcûrî Rabbi Yessir Umûrî

el-Fakîru ileyhi te 'âlâ Alî Hicâzî eş-Şemmârî el-Mâlikî afâ anh [Mühür] Alî Şemmârî

el-Fakîr Mahmûd es-Serhîmî(?) eş-Şâfi'î bi'l-Ezher afâ anh [Mühür Okunmuyor] 
$E k: 2$

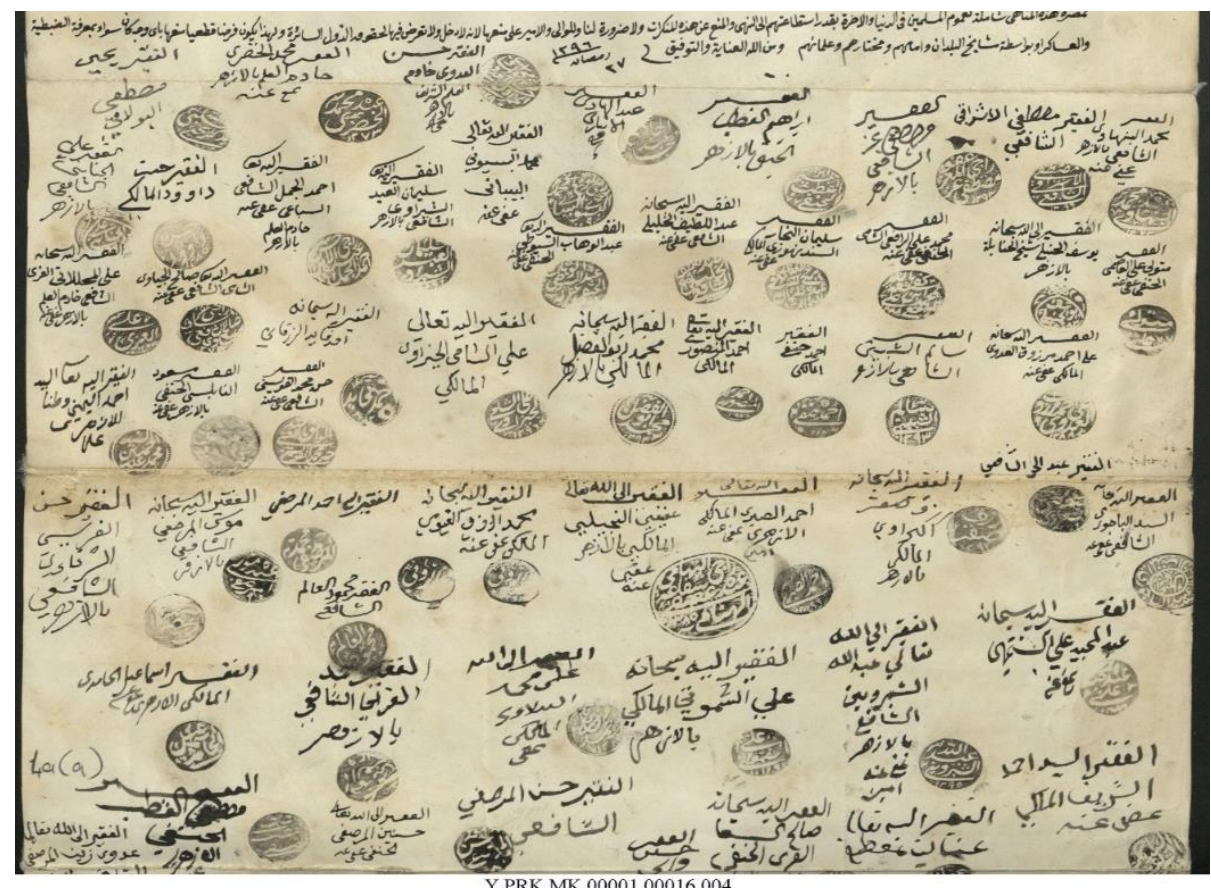

Y PRK MK 0000100016.004

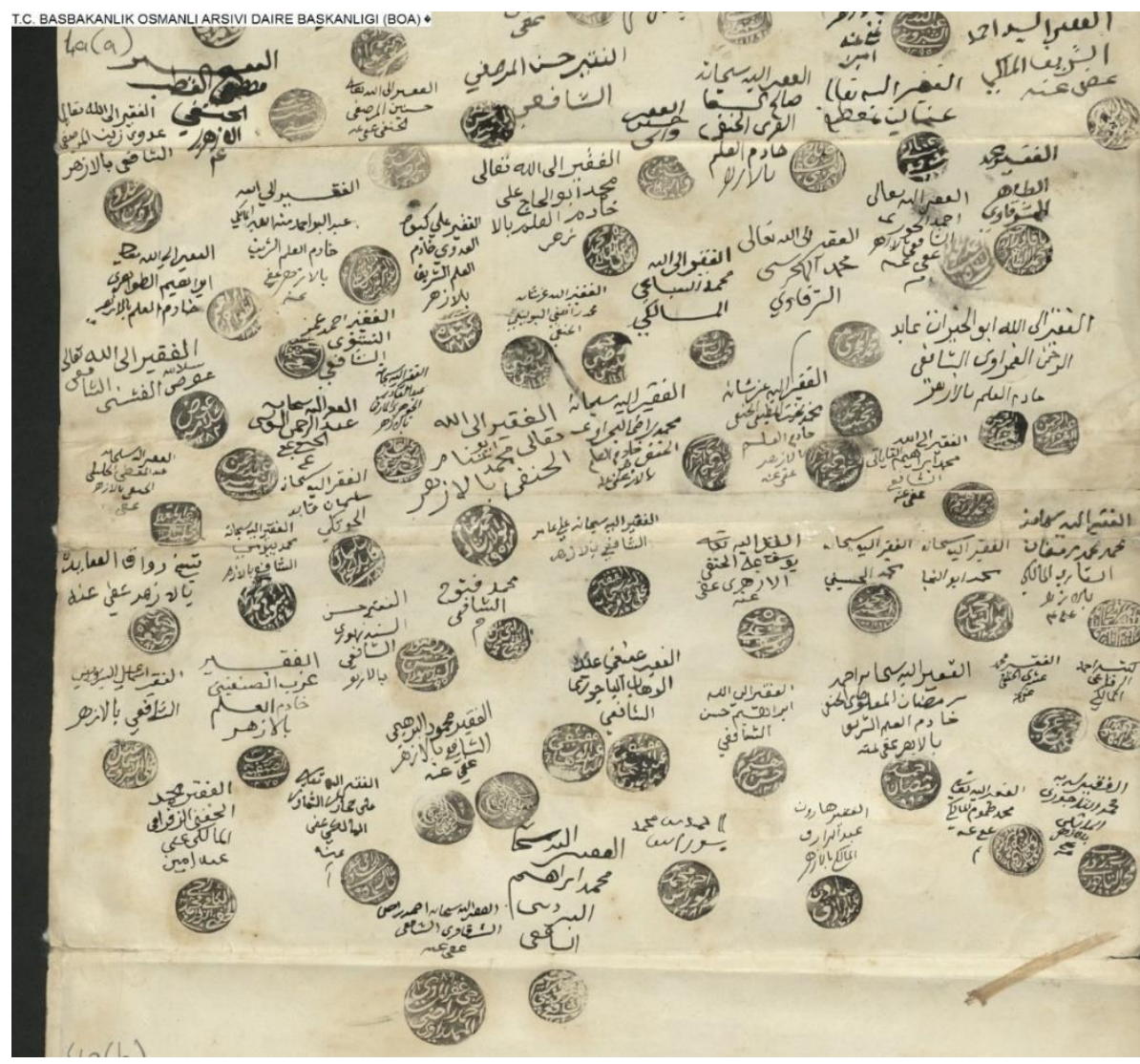

